\title{
The Applicability of Army Design Methodology to the Federal Bureau of Investigation
}

\author{
A Monograph \\ by \\ Supervisory Special Agent Kevin L. Blair \\ Federal Bureau of Investigation
}

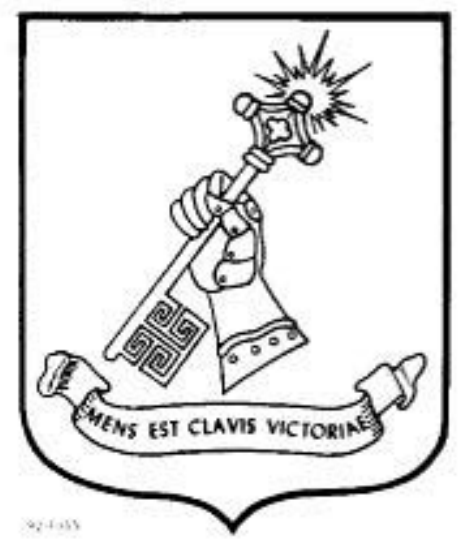

School of Advanced Military Studies

United States Army Command and General Staff College

Fort Leavenworth, Kansas

AY 2011 


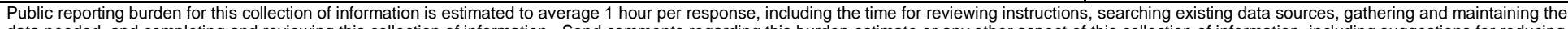

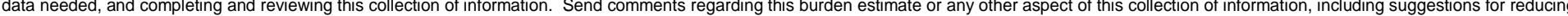

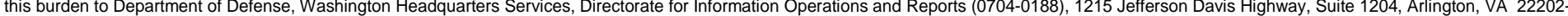

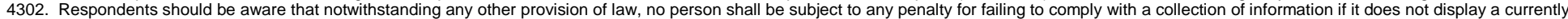
valid OMB control number. PLEASE DO NOT RETURN YOUR FORM TO THE ABOVE ADDRESS.

\begin{tabular}{l|l|l} 
1. REPORT DATE (DD-MM-YYYY) & 2. REPORT TYPE & 3. DATES COVERED (FrOm - To)
\end{tabular}

19-05-2011

SAMS Monograph

June 2010 - May 2011

4. TITLE AND SUBTITLE

The Applicability of Army Design Methodology to the Federal

Bureau of Investigation

5a. CONTRACT NUMBER

5b. GRANT NUMBER

5c. PROGRAM ELEMENT NUMBER

6. AUTHOR(S)

Supervisory Special Agent Kevin L. Blair FBI

5d. PROJECT NUMBER

5e. TASK NUMBER

5f. WORK UNIT NUMBER

7. PERFORMING ORGANIZATION NAME(S) AND ADDRESS(ES)

School of Advanced Military Studies (SAMS)

8. PERFORMING ORGANIZATION REPORT

250 Gibbon Avenue

Fort Leavenworth, KS 66027-2134

9. SPONSORING I MONITORING AGENCY NAME(S) AND ADDRESS(ES)

Command and General Staff College

10. SPONSOR/MONITOR'S ACRONYM(S)

731 McClellan Avenue

Fort Leavenworth, KS 66027-1350 NUMBER

12. DISTRIBUTION I AVAILABILITY STATEMENT

Approved for Public Release; Distribution Unlimited

\section{SUPPLEMENTARY NOTES}

\section{ABSTRACT}

The FBI has a long history and established culture as the pre-eminent law enforcement agency in the world. Beginning in the late 1930s, the FBI assumed responsibility for espionage and domestic intelligence investigations. Abuses of domestic intelligence investigations in the 1950s and 1960s led to the Church Committee hearings of the 1970s. Those hearings showed the FBI had abused its investigative powers, and several senior FBI officials were indicted. Subsequently, intelligence investigations and programs were avoided by most FBI personnel, and the intelligence program was unable to detect and prevent the $9 / 11$ attacks.

Following 9/11, the FBI sought to transform itself into an effective domestic intelligence agency by implementing a series of bureaucratic programs and policies. Eight years later, the Fort Hood attack, and the subsequent Congressional report, indicated the FBI's transformation needed to be accelerated. Had the concept of design been available to FBI Intelligence Program leaders and applied to the problem, the need to deal with the FBI's law enforcement culture concurrently with establishment of bureaucratic policies and procedures would have been apparent. By applying design to the Intelligence Program, a need for post-9/11 cultural transformation becomes clear. As the world becomes both more complex and interconnected, the FBI needs to adapt and evolve to meet new challenges. By developing and applying its own design concept, the FBI can avoid the transformational problems of the past ten years in the future. The FBI will continue to be faced with complex, ill-structured problems, and can benefit by establishing a design process to apply to those problems.

\section{SUBJECT TERMS}

16. SECURITY CLASSIFICATION OF:

(U)

\section{a. REPORT}

(U)

b. ABSTRACT

(U)

c. THIS PAGE

(U)
17. LIMITATION OF ABSTRACT

(U)
18. NUMBER OF PAGES

(U) 19a. NAME OF RESPONSIBLE PERSON

Wayne W. Grigsby Jr.

COL, U.S. Army

19b. TELEPHONE NUMBER (include area code)

$913-758-3302$ 


\section{SCHOOL OF ADVANCED MILITARY STUDIES MONOGRAPH APPROVAL}

Supervisory Special Agent Kevin L. Blair

Title of Monograph: The Applicability of Army Design Methodology to the Federal Bureau of Investigation

Approved by:

Robert W. Tomlinson, Sr.

Monograph Director

Second Reader

Gerald S. Gorman, Ph.D.

Wayne W. Grigsby, Jr., COL, IN

Director, School of Advanced Military Studies

Robert F. Baumann, Ph.D.

Director, Graduate Degree Programs 
Disclaimer: Opinions, conclusions, and recommendations expressed or implied within are solely those of the author, and do not represent the views of the US Army School of Advanced Military Studies, the US Army Command and General Staff College, the United States Army, the Department of Defense, or any other US government agency. Cleared for public release: distribution unlimited. 


\begin{abstract}
The Applicability of Army Design Methodology to the Federal Bureau of Investigation by Supervisory Special Agent Kevin L. Blair, Federal Bureau of Investigation, 54 pages.

The FBI has a long history and established culture as the pre-eminent law enforcement agency in the world. Beginning in the late 1930s, the FBI assumed responsibility for espionage and domestic intelligence investigations. Abuses of domestic intelligence investigations in the 1950s and 1960s led to the Church Committee hearings of the 1970s. Those hearings showed the FBI had abused its investigative powers, and several senior FBI officials were indicted. Subsequently, intelligence investigations and programs were avoided by most FBI personnel, and the intelligence program was unable to detect and prevent the $9 / 11$ attacks.
\end{abstract}

Following 9/11, the FBI sought to transform itself into an effective domestic intelligence agency by implementing a series of bureaucratic programs and policies. Eight years later, the Fort Hood attack, and the subsequent Congressional report, indicated the FBI's transformation needed to be accelerated. Had the concept of design been available to FBI Intelligence Program leaders and applied to the problem, the need to deal with the FBI's law enforcement culture concurrently with establishment of bureaucratic policies and procedures would have been apparent. By applying design to the Intelligence Program, a need for post-9/11 cultural transformation becomes clear. As the world becomes both more complex and interconnected, the FBI needs to adapt and evolve to meet new challenges. By developing and applying its own design concept, the FBI can avoid the transformational problems of the past ten years in the future. The FBI will continue to be faced with complex, ill-structured problems, and can benefit by establishing a design process to apply to those problems. 


\section{Table of Contents}

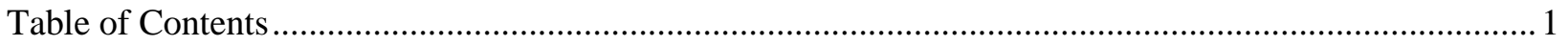

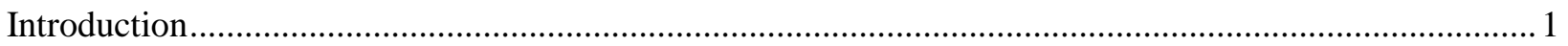

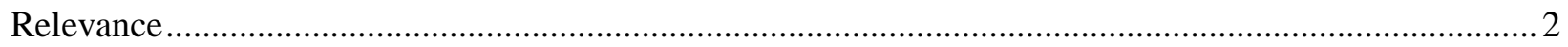

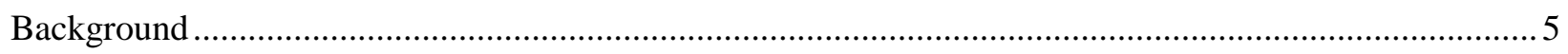

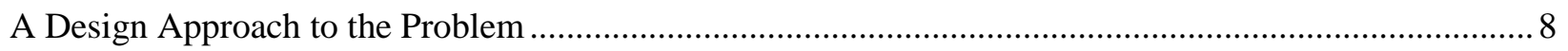

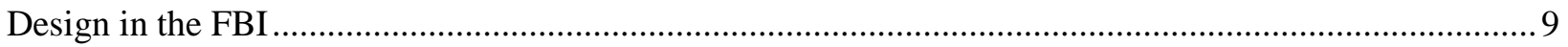

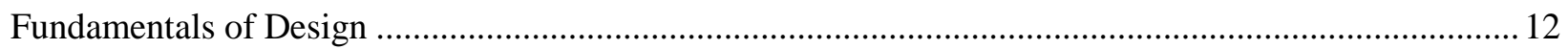

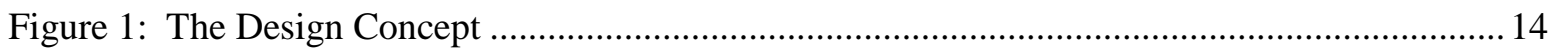

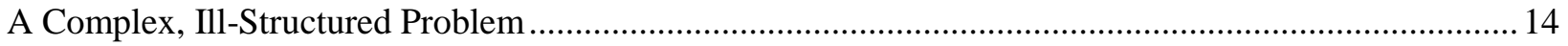

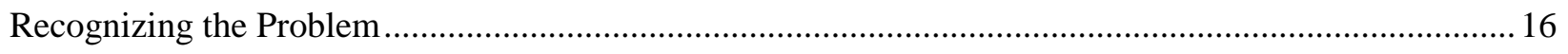

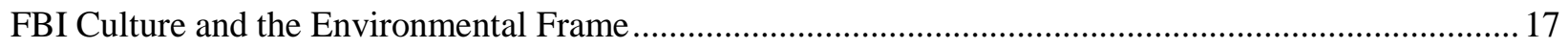

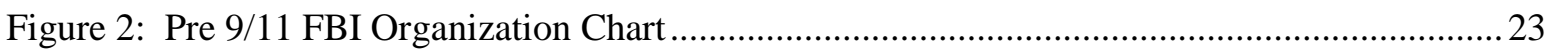

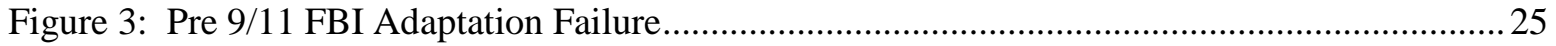

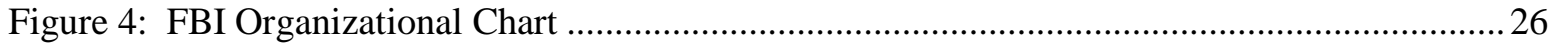

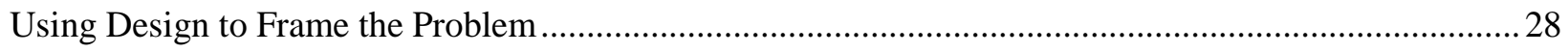

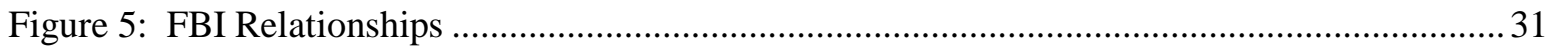

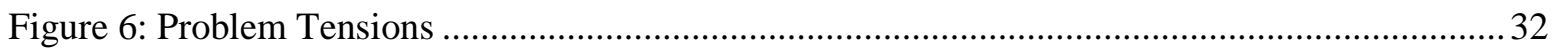

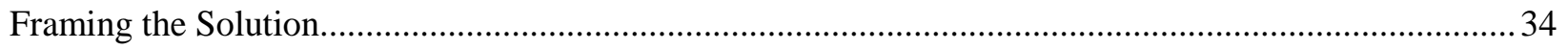

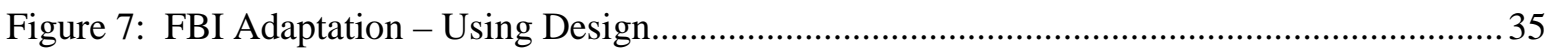




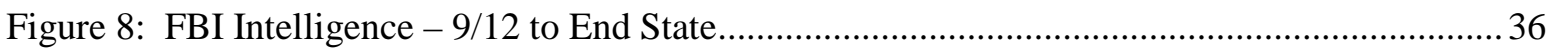

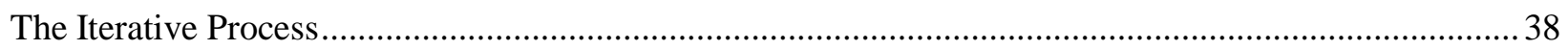

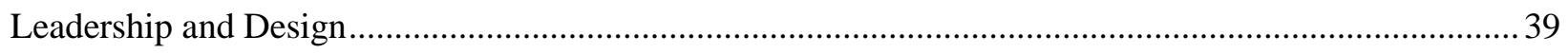

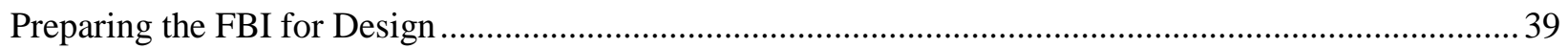

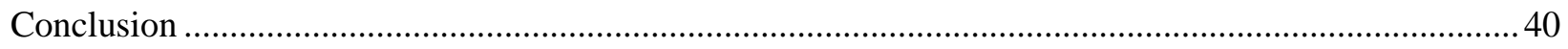

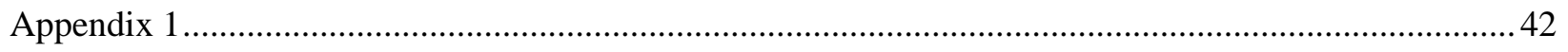

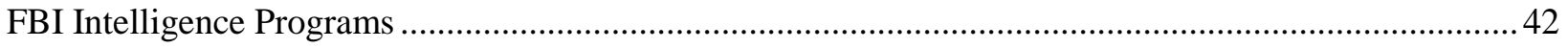

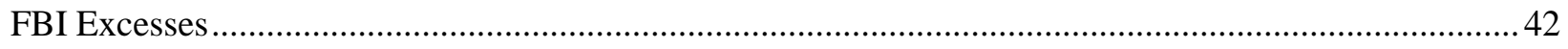

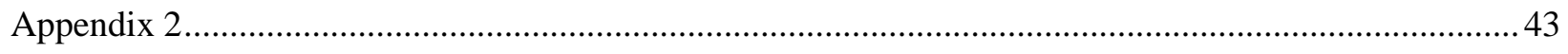

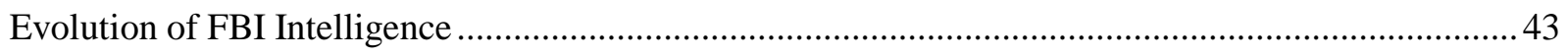

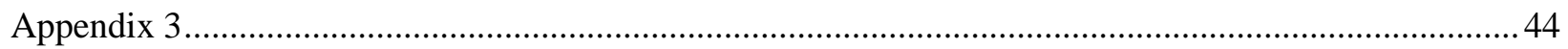

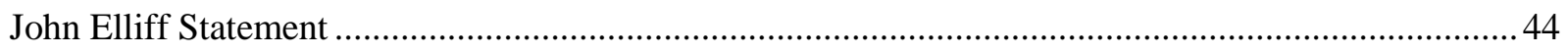

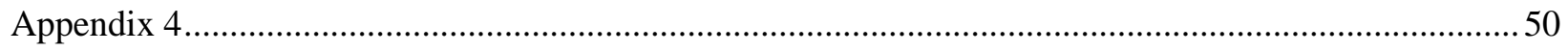

Terrorist Screening Center Director Donna A. Bucella’s Statement to the National Commission on

Terrorist Attacks Upon the United States, January 26, 2004 .............................................................. 50

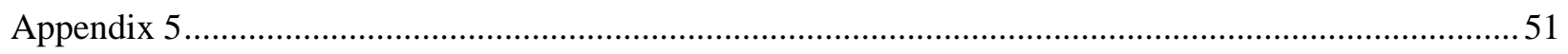

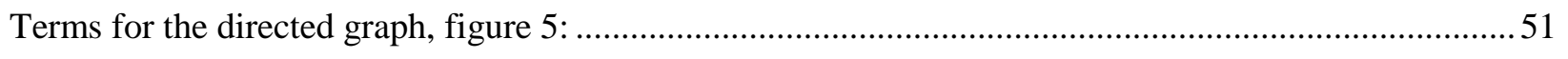

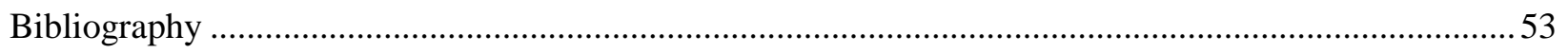




\section{Introduction}

The parallels to real situations were obvious. Here, as in the real world, we found that our decision makers

- Acted without prior analysis of the situation,

- $\quad$ Failed to anticipate side effects and long-term repercussions,

- Assumed that the absence of immediately obvious negative effects meant that correct measures had been taken,

- Let overinvolvement in 'projects' blind them to emerging needs and changes in the situation

- Were prone to cynical reactions.

-Dietrich Dörner, The Logic of Failure

Can design be applied to complex, ill-structured problems within the bureaucracy of the Federal Bureau of Investigation (FBI)? Should the FBI develop a design methodology to enable the organization to more quickly adapt to emerging problems? The FBI has traditionally used a bureaucratic approach to solving problems, but an increasingly complex and interconnected society requires agility and flexibility. Developed since the mid-1990s by the Israelis, and now modified into Army doctrine, "Design is a methodology of applying critical and creative thinking to understand, visualize and describe complex, illstructured problems and develop approaches to solve them.” ${ }^{\prime 1}$ Design is an approach which considers the environment, problem and solution as a connected web in which a change to one area affects the others. The commander leads and encourages discourse toward the development of a narrative which explains the logic of the environment and becomes the basis of the operation. The Federal Bureau of Investigation (FBI) has added several new divisions and directorates since September 11, 2001, each to address a complex, ill-structured problem. For example, prior to September 11, the FBI had no Security Division, Intelligence Directorate, or Records Management Division. Each was established in response to a problem exposed in a significant negative event, the arrest of FBI agent/Soviet spy Robert Hanssen, the intelligence failures of 9/11, and the failure to provide investigative records to Oklahoma City bomber

\footnotetext{
${ }^{1}$ Department of the Army, FM 5-OThe Operations Process, Washington, DC: Headquarters, Department of the Army, 2010, p 3-1
} 
Timothy McVeigh during his judicial process. The issues exposed by these events were deeply rooted in FBI culture and history, factors which a design process can identify and engage. Could the FBI benefit from the application of the Army's doctrinal design process? Using FBI history and a variety of government reports to provide a basis for FBI culture and the need for transformation, this paper will apply design to the FBI's Intelligence Program as it existed on September 12, 2001 to demonstrate the potential for design and the need for FBI development and application of a design methodology.

\section{Relevance}

The FBI's inquiry into Hasan was impeded by division among its field offices, insufficient use of intelligence analysis, and outdated tradecraft. The FBI has made substantial strides since 9/11 in reorganizing itself and reorienting its investigative processes to generate intelligence and ultimately to prevent domestic terrorist attacks. The FBI has been successful in disrupting many terrorist plots. However, the Fort Hood case suggests that the FBI's transformation to become an efficient and effective intelligence driven organization focused on preventing domestic terrorist attacks is unfinished. The creation of new institutions within the FBI sometimes has not been accompanied by clear business processes that articulate these new institutions' responsibilities and authorities within the FBI. As a result, these new institutions may not have achieved the transformation of the FBI that was desired.

- U.S. Senate Committee on Homeland Security and Governmental Affairs,

A Ticking

Time Bomb, Counterterrorism Lessons from the U.S. Government's Failure to Prevent the Fort Hood Attack

Commissions, think tanks, government agencies, and individuals have studied the September 11, 2001 terrorist attacks to determine causes of extremism, U.S. intelligence failures, economic effects, health of first responders and many other topics. Taken together, the reports, studies, books and academic articles provide a portrait of intelligence agencies and extremist organizations as they engage in their respective battles to defend and attack Western society. One of the first comprehensive reports to be published, the report of the Joint Inquiry into Intelligence Community Activities Before and After the Terrorist Attacks of September 11, 2001 (Joint Inquiry), summarized Intelligence Community issues in their first finding: 
Prior to September 11, the Intelligence Community was neither well organized nor equipped, and did not adequately adapt, to meet the challenge posed by global terrorists focused on targets within the domestic United States. Serious gaps existed between the collection coverage provided by U.S. foreign and U.S. domestic intelligence capabilities. The U.S. foreign intelligence agencies paid inadequate attention to the potential for a domestic attack. The CIA's failure to watchlist suspected terrorists aggressively reflected a lack of emphasis on a process designed to protect the homeland from the terrorist threat. As a result, CIA employees failed to watchlist alMihdhar and al-Hazmi. At home, the counterterrorism effort suffered from the lack of an effective domestic intelligence capability. The FBI was unable to identify and monitor effectively the extent of activity by al-Qa'ida and other international terrorist groups operating in the United States. Taken together, these problems greatly exacerbated the nation's vulnerability to an increasingly dangerous and immediate international terrorist threat inside the United States. ${ }^{2}$

Organization, equipment and adaptation are the three shortcomings noted first in this inquiry. The FBI has a long history of fighting crime, terrorism and espionage, while responding to new threats by organizing, equipping and adapting. Throughout the gangster era of the 1930s, the FBI armed its agents for the first time, and organized itself to fight gangsters who were accustomed to committing violent crimes and crossing state lines to avoid the law. ${ }^{3}$ Some of the better known criminals arrested or killed by the FBI included John Dillinger, Charles Arthur “Pretty Boy” Floyd, and George "Machine Gun” Kelly. ${ }^{4}$ Following the FBI's success in the 1930s, President Roosevelt assigned the FBI to fight spies, sabotage and espionage. The FBI organized and adapted to meet this assignment, expanding from 851 agents in 1939 to approximately 4600 in 1943, and hired an additional 5,000 non-agents. ${ }^{5}$ During World War II, the FBI adapted to the mission of "counter sabotage," and successfully prevented attacks on manufacturing plants. During the Cold War, the FBI adapted to the threat of Communist spies and espionage. Following the fall of the Iron Curtain, the FBI began to focus on terrorism, but the failure to adapt by restructuring its organization and equip itself in the face of an emerging challenge led to its failure to correctly assess al-Qaeda and its intentions and to prevent the September 11 attacks. FBI Director Robert Mueller

\footnotetext{
${ }^{2}$ Joint Inquiry into Intelligence Community Activities Before and After the Terrorist Attacks of September 11, 2001, Report of the U.S. Senate Select committee on Intelligence and U.S. House permanent Select Committee on Intelligence, 2002 p. xv (Joint Inquiry)

${ }^{3}$ Collins,Frederick L., The FBI in Peace and War, G.P. Putnam and Sons, New York 1962, p. 35

${ }^{4}$ Masse, Todd and Krouse, William, The FBI: Past, Present, and Future, Congressional Research Service, 2003 p. 8 ${ }^{5}$ Collins, p.50
} 
recognized the FBI's problems ${ }^{6}$, and embarked on an ambitious agenda to transform the FBI into an effective domestic intelligence agency with the goal of preventing terrorist attacks and serious crime. ${ }^{7}$ These efforts have had a significant effect on the FBI's intelligence processes, ${ }^{8}$ but the Intelligence Community ${ }^{9}$ and Congress ${ }^{10}$ remain critical of the FBI's progress. The February 2011 Senate report on the Fort Hood shootings noted: “...the Fort Hood attack is an indicator that the current status of the FBI's transformation to become intelligence-driven is incomplete and that the FBI faces internal challenges which may include cultural barriers - that can frustrate the on-going institutional reforms. The FBI needs to accelerate its transformation."11 Despite the Director's recognition of the need to transform the FBI, the Fort Hood attack demonstrated that eight years of new bureaucracy and processes did not solve the complex, ill-structured problems the FBI faced.

As the tenth anniversary of the September $11^{\text {th }}$ attacks approaches, it is relevant to ask whether a different approach could have been taken to the organization, equipment and adaptation shortcomings noted in the Joint Inquiry. In 2005 the U.S. Army began to seriously consider an Israeli-developed concept, Systemic Operational Design (SOD), as an approach to understanding complex, ill-structured problems, such as those presented by the Iraq conflict. Had it been available to FBI executives on September 12, 2001, would the use of design have shortened the time needed for the FBI to transform itself into an effective domestic intelligence agency, fully integrated and accepted into the Intelligence Community? Would the application of design have improved the performance of the FBI's current

\footnotetext{
${ }^{6}$ In a speech to the Conference of Mayors on October 24, 2001, Director Mueller acknowledged the FBI’s new priority of attack prevention and a number of problems associated with timely information sharing.

${ }^{7}$ Maureen Baginski, interview by author, Fairfax, VA, December 23, 2010

${ }^{8}$ Rivkin, Jan W., Roberto, Michael, Gulati, Ranjay. Federal Bureau of Investigation, 2009, Cambridge, Harvard Business School 2009, p. 8

${ }^{9}$ Baginski, interview

${ }^{10}$ House Intelligence Committee Member, conversation with author, July 27, 2010

${ }^{11}$ U.S. Senate Committee on Homeland Security and Governmental Affairs, A Ticking Time Bomb, Counterterrorism Lessons from the U.S. Government's Failure to Prevent the Fort Hood Attack, p. 9 (Ft Hood report)
} 
intelligence program? This monograph will provide a brief history of FBI intelligence gathering operations, and discuss some of the organizational, equipment and adaptation problems which led to the intelligence failures of 9/11, as well as the FBI's methods for solving those problems. Within the context of the FBI, design will be defined and applied to the same problems to demonstrate how design illuminates the complexities of agency culture and provides insight into alternatives for fixing the FBI's intelligence program as it stood the day after 9/11.

\section{Background}

FBI intelligence operations pose difficult problems for a nation committed to constitutional government and the rule of law. We live in a world where acts of terrorist violence and foreign espionage are considered serious present dangers to the security of the United States.

-John T. Elliff, The Reform of FBI Intelligence Operations

Successfully preventing terrorist attacks by gathering and disseminating intelligence in a society which guarantees an individual's rights to free speech and due process is a complex and ill-structured problem. ${ }^{12}$ For over 100 years the FBI has collected information on both Americans and non-Americans around the world, sometimes lawfully, and sometimes not. ${ }^{13}$ Many reports have detailed the failures of the Intelligence Community (IC) and the FBI in particular, for not properly dealing with the famous “Phoenix Memo” or the Milwaukee Division’s requests on Zacarias Moussaoui. For example, the “Congressional Joint Inquiry Into Intelligence Community Activities Before and After the Terrorist Attacks of September 11, 2001, criticized the FBI for failing to focus on the terrorist threat domestically; collect useful intelligence; strategically analyze intelligence; and, to share intelligence internally, and with the rest of the IC. Prior to 9/11, according to the congressional inquiry, the FBI was incapable of

\footnotetext{
${ }^{12}$ In an April 26, 2007 speech titled "How the FBI Defends American Lives While Defending American Liberties" at Harvard University on April 26, 2007, Director Mueller discusses the complexities of intelligence operations.

${ }^{13}$ Elliff, p. 6. A Department of Justice investigation in 1977-78 resulted in indictments of former FBI officials.
} 
producing significant intelligence products and was seriously handicapped in its efforts to identify, report on, and defend against the foreign terrorist threat to the United States.”14

As documented in a Congressional Research Service Report, "In response to criticisms of its role in this failure, the Federal Bureau of Investigation (FBI) has introduced a series of reforms to transform the bureau from a largely reactive law enforcement agency focused on criminal investigations into a more mobile, agile, flexible, intelligence-driven agency that can prevent acts of terrorism.” ${ }^{15}$ Much of the FBI’s focus has been on the creation and building of the former Office of Intelligence, now known as the Directorate of Intelligence. Despite the vast experience and best intentions of personnel within the Directorate of Intelligence and FBI senior management, “By 2007...pressures were mounting inside and outside the Bureau to accelerate the intelligence cycle.”" ${ }^{16}$ One consultant noted: "The goal of an intelligence-led, threat-based FBI was clear... One problem was that FBI personnel had already been through lots of change efforts since 9/11, and many of them had stalled out." ${ }^{17}$

The "stalled out” change efforts which began in November 2001 could not succeed in an organization whose culture existed as a "largely reactive law enforcement agency.” A 2004 Department of Justice Office of the Inspector General Report titled: “A Review of the FBI's Handling of Intelligence Information Related to the September 11 Attacks,” lists five fundamental problems: ineffective system for assigning and managing work; lack of adequate strategic analytical capabilities; resources and training

\footnotetext{
${ }^{14}$ Cumming, Alfred and Masse, Todd. Intelligence Reform Implementation at the Federal Bureau of Investigation: Issues and Options for Congress, Washington, DC: Library of Congress 2005 from the Joint Inquiry Into Intelligence Community Activities Before and After the Terrorist Attacks of September 11, 2001, a report of the U.S. Congress, Senate Select Committee on Intelligence and the House Permanent Select Committee on Intelligence, S.Rept. 107-351; H.Rept. 107-792, Dec. 2002

${ }^{15}$ Cumming, Alfred and Masse. Todd FBI Intelligence Reform Since September 11, 2001: Issues and Options for Congress, Washington, DC: Library of Congress, 2004, p. 6

${ }^{16}$ Rivkin, Jan W., Roberto, Michael, Gulati, Ranjay. Federal Bureau of Investigation, 2009, Cambridge, Harvard Business School 2009, p. 2

${ }^{17}$ Ibid
} 
for analysts; poor information flow and information sharing; and general complaints about the difficulties of working in ITOS (International Terrorism Operations Section). ${ }^{18}$

The hiring of a senior intelligence community professional in May 2003 to the post of FBI Executive Assistant Director (EAD) for Intelligence led to the first initiative to reevaluate how the FBI structured and conducted its intelligence operations. EAD Baginski’s 10-week initiative produced concepts of operations that provided a framework for improving each of nine core intelligence functions defined by the FBI: Community Support, FBI Intelligence Assessment Process, FBI Intelligence Requirements and Collection Management Process, FBI Field Office Intelligence Operations, Forecasting Intelligence Program Operational Requirements, Human Talent for Intelligence Production, Integrated Information Sharing, Intelligence Production and Use, and Intelligence Program Budget Formulation Process. ${ }^{19}$

These concepts were provided to Headquarters and field offices as they were approved, and were one element of the "lots of change efforts" previously noted. Two years later, in August 2005, the Congressional Research Service reported: "While areas of promise exist, field research indicates that the FBI’s ability to formally harness intelligence collection (including systemic accountability mechanisms) to analytically identified intelligence gaps, remains nascent.”20

In 2001, the United States was attacked, and despite sincere efforts of many dedicated personnel, the FBI intelligence performance was still "nascent” in 2005, and in 2007 the FBI was being pressured to accelerate the intelligence cycle. In February 2011, the Senate report on the Fort Hood attack again noted that “...the FBI’s transformation into an ‘intelligence-driven’ domestic counterterrorism organization

\footnotetext{
${ }^{18}$ Department of Justice, A Review of the FBI's Handling of Intelligence Information Related to the September 11 Attacks, Washington, DC, 2004

${ }^{19}$ Department of Justice, The Federal Bureau of Investigation's Efforts to Improve the Sharing of Intelligence and Other Information, Washington, DC 2003

${ }^{20}$ Cumming, Alfred and Masse, Todd, Intelligence Reform Implementation at the Federal Bureau of Investigation: Issues and Options for Congress, Washington, DC: Library of Congress 2005, p. 2
} 
needs to be accelerated,"21 leaving no question that the FBI's operations within the intelligence cycle and prevention of terrorist attacks are still components of a complex and ill-structured problem.

\section{A Design Approach to the Problem}

Design does not replace planning, but planning is incomplete without design. The balance between the two varies from operation to operation as well as within each operation. Operational design must help the commander provide enough structure to an ill-structured problem so that planning can lead to effective action toward strategic objectives. Executed correctly, the two processes always are complementary, overlapping, synergistic, and continuous.

-General James N. Mattis, Memorandum for U.S. Joint Forces Command: Vision for a Joint Approach to Operational Design

In the mid-1990s the Israel Defense Force think tank, the Operational Theory Research Institute,

first began to develop Systemic Operational Design (SOD). By 2005, the U.S. Army, heavily involved in an insurgency in Iraq, had developed an interest in design and its potential in addressing the cultural component of the conflict. ${ }^{22}$ As noted in the introduction to the Art of Design Student Text:

So it was in 2005 that the first eight students from the Advanced Military Studies Program (AMSP) were selected to study and practice SOD. In May, the group participated in Exercise Unified Quest 2005, to compare the outcomes of SOD with those of two other groups, one using Effects Based Operations (EBO) and the other the Military Decision Making Process (MDMP). Their design caught the attention of several senior officers at Unified Quest because something different was going on. The logic of the approach was different: it began with a holistic inquiry into the nature of the rival in context and came to its own understanding of 'the problem.' These aspects combined in the discourses of SOD generated both critical and creative thought. Because the inquiry was holistic, the SOD team produced a very different recommendation within the scenario - an indirect and non-military disruption of the rival system. $^{23}$

Although the Israel Defense Force had begun looking at SOD in the mid-1990s, it took a war, followed by an insurgency, to bring design into the U.S. Army’s area of interest. In 2005, two years after the FBI had begun to develop their Directorate of Intelligence, the Army had preliminarily codified design and exercise-tested it. Design was not a concept known to Directorate of Intelligence executives,

\footnotetext{
${ }^{21}$ Ft Hood report, p. 43

${ }^{22}$ Banach, Stefan J., et al, Art of Design Student Text Version 2.0, Fort Leavenworth, School of Advanced Military Studies, 2010, p. 1

${ }^{23}$ Ibid p. 2
} 
and so could not have been used in the Directorate's creation and operation. ${ }^{24}$ Another FBI entity, the Terrorist Screening Center, was also created in 2003. Executives at the Terrorist Screening Center were not aware of design, yet their initial and subsequent success and growth was built on the foundation of a design approach. Strong leadership, consideration of the environment, understanding the problem, an innovative and adaptive solution and iterative processes were all characteristic of the Center's executives and planners. ${ }^{25}$

\section{Design in the FBI}

The very word 'design' is the first problem we must confront...since it is in everyday use and yet given quite specific and different meanings...

-Bryan Lawson, How Designers Think

In FM 5-0, The Operations Process, Chapter 3, “Design,” provides military planners with a different concept for planning and operations. As defined in paragraph 3-1, "Design is a methodology of applying critical and creative thinking to understand, visualize and describe complex, ill-structured problems and develop approaches to solve them. ${ }^{\text {,2 }}$ Had the concept of design been available and applied to the FBI's intelligence program on September 12, 2001, the FBI may have been able to more completely identify and define the problem, leading to a more comprehensive solution being implemented with greater expedience.

The FBI is no stranger to identifying the problem and dealing with complex, ill-structured problems. Some agents unwittingly use design principles to formulate case investigative strategies, and

\footnotetext{
${ }^{24}$ Baginski, interview

${ }^{25}$ Timothy Healy, interview by author, Arlington, VA, January 27, 2011

${ }^{26}$ Department of the Army, FM 5-0 The Operations Process, Washington, DC, Headquarters, Department of the Army, 2010, p 3-1
} 
there are two FBI-led organizations which initially formed and operated using conceptual design, the Terrorist Screening Center (TSC) and the Internet Fraud Complaint Center (IFCC). The TSC's design base is evident from the TSC Director's statement to the National Commission on Terrorist Attacks Upon the United States in January 2004 (only a month after being established), in which she provided an environmental narrative resulting from application of a conceptual design process. ${ }^{27}$ Gharajedaghi described this process as “reformulation," which included phases for searching, mapping and telling the story (narrative). ${ }^{28}$ This narrative differs from conventional descriptions, which lists facts and assumptions. ${ }^{29}$ Because they must have a coherent beginning, middle, and end, a plot, a moral, and a point of view, narratives go beyond describing facts. ${ }^{30}$ At the TSC, experts from across government and the private sector were consulted to create an approach which considered the environment, the problem and the solution. Both the Director and the Principal Deputy Director were deeply involved in all aspects of the design, and their phased plan has endured eight years of operations and growth, allowing for technological updates, personnel changes, terrorist tactic development, and the effects of two wars.

The TSC’s first Principal Deputy Director, FBI Supervisory Special Agent Timothy Healy, had been in the FBI since 1984, and had investigated a series of increasingly complex cases. As his cases became more complex, they involved additional FBI offices, then non-local police departments, and finally multiple international jurisdictions. The last of these investigations, “Canadian Eagle,” ${ }^{31}$ required extensive liaison, manpower, memoranda of agreement between local, state, federal and international authorities, and budget approval. Healy’s original investigative design for Canadian Eagle has now been

\footnotetext{
${ }^{27}$ A portion of the testimony is contained in Appendix 4

${ }^{28}$ Gharajedaghi, Jamshid, Systems Thinking, London, Elsevier, 2006 p. 132

${ }^{29}$ Art of Design Student Text, p.15

${ }^{30}$ Ochs, Elinor and Capps, Lisa, “Narrating the Self,” Annual Review of Anthropology 25 (1996): 19-43

31 "Canadian Eagle” is the title of a joint FBI-Royal Canadian Mounted Police initiative to address telemarketing fraud originating in Canada. While most of the victims were in the U.S., nearly all of the perpetrators were located in Canada, leading to complex jurisdictional, evidentiary, and legal issues.
} 
in place and successful since 1997. The concept of design was used at the TSC simply because Healy had always applied that approach, learning through trial and error. ${ }^{32}$

On arriving at the TSC, Healy found 100 developers and contractors working on projects without knowledge of how their project fit with the larger program. Because the President and FBI Director had pledged to launch the TSC's operations within 26 days of his arrival, Healy knew the situation was both complex and ill-structured. Working from a previously completed concept of operations, Healy assembled a team with participants from several agencies involved in terrorist watch listing. The team began by interviewing the 100 contractors to determine their skills and current projects (in Gharajedaghi's process, searching), and then began to break down the entire watch listing process for each agency to analyze and develop process flows (Gharajedaghi's mapping). As each process was diagrammed and integrated into the TSC's concept of operations, decision/action points became clear. The decision/action points were determined to have solutions based on information technology (making systems communicate with each other), standing operating procedure (did the current SOP work, or was another, more efficient one required), or a memorandum of understanding (ensuring multiple agencies appropriately shared information and provided expertise, personnel, or budget). Once the processes were designed and integrated with the concept of operations, the detailed planners could work on their assigned decision/action points, while understanding where their role fit into the larger TSC function. ${ }^{33}$ In Systems Thinking, Gharajedaghi describes the mapping process followed intuitively by Healy’s team: “Systems analysis provided a non-judgmental picture of the system as it is. Obstructions analysis identified sets of internal and external obstructions that co-produced the mess. The search process categorized the obstructions around major themes. Generation of the themes involved extensive discussions so that a shared understanding of the grouping criteria was achieved.”34 Healy used a similar approach when

\footnotetext{
${ }^{32}$ Healy, interview

33 Ibid

${ }^{34}$ Gharajedaghi, p. 141
} 
creating the Internet Fraud Complaint Center ${ }^{35}$, which handled over 28,000 complaints per month in $2009 .{ }^{36}$

The early leaders of the FBI's Directorate of Intelligence applied a more traditional approach which established a much-needed program that succeeded in some aspects without the application of design. As noted by the 2005 WMD Commission Report, “The FBI has spent the past three and a half years building the beginnings of an intelligence service and striving to transform itself into a hybrid law enforcement and intelligence agency. Field offices now routinely cull intelligence information from operations and investigations, and disseminate Intelligence Information Reports. An intelligence official from another law enforcement agency praised the FBI's ability to extract pertinent information from cases, pointing out that ‘they are doing a better job than anybody could have expected.”,37

\section{Fundamentals of Design}

Despite efforts to discover the foundations of design thinking in the fine arts, the natural sciences, or most recently, the social sciences, design eludes reduction and remains a surprisingly flexible activity. No single definition of design, or branches of professionalized practice such as industrial or graphic design, adequately covers the diversity of ideas and methods gathered together under the label.”

-Richard Buchanan, Wicked Problems in Design Thinking, The Idea of Design

Design is a methodology for applying critical and creative thinking to understand, visualize, and describe complex, ill-structured problems and develop approaches to solve them. ${ }^{38}$ In reviewing FM 3-0

\footnotetext{
35 The Internet Fraud Complaint Center's name was changed to the Internet Crime Complaint Center in 2003 to more appropriately reflect their mission.

${ }^{36}$ Internet Crime Complaint Center, 2009 Internet Crime Report, accessed at: http://www.ic3.gov/media/annualreport/2009_IC3Report.pdf on 5/10/11

${ }^{37}$ WMD Commission Report, p. 452

${ }^{38}$ FM 5-0 The Operations Process, p. 3-1
} 
and the Art of Design Student Text, several concepts of design are fundamental: ${ }^{39}$ Design is continuous throughout planning and evolves with increased understanding throughout the operations process. Design requires effective and decisive leadership that engages subordinate commanders, coordinating authorities, representatives of various staff disciplines, and the higher commander in continuing collaboration and dialog that leads to enhanced decision making. Innovation, adaptation, and continuous learning are central tenets of design. The goals of design are: Understanding ill-structured problems; Anticipating change; Creating opportunities, and; Recognizing and managing transitions. The fundamentals of design are: Apply critical thinking; Understand the operational environment; Solve the right problem; Adapt to dynamic conditions, and; Achieve the designated goals. A creative design tailored to a unique operational environment promises: Economy of effort; Greater coherence across rotations among units and between successive operations; Better integration and coordination among the instruments of national power; Fewer unintended consequences, and; Effective adaptation once the situation changes. The desired end state consists of those desired conditions that, if achieved, meet the objectives of policy, orders, guidance, and directives issued to the commander. Three distinctive elements collectively produce a design concept as depicted below. The below graphic provides a visual reminder that all three elements are connected, and one cannot be affected without a change in the other two, thus producing the iterative adaptation described above.

\footnotetext{
${ }^{39}$ This section is summarized from FM 5-0, pages 3-1 to 3-9
} 
Figure 1: The Design Concept ${ }^{40}$

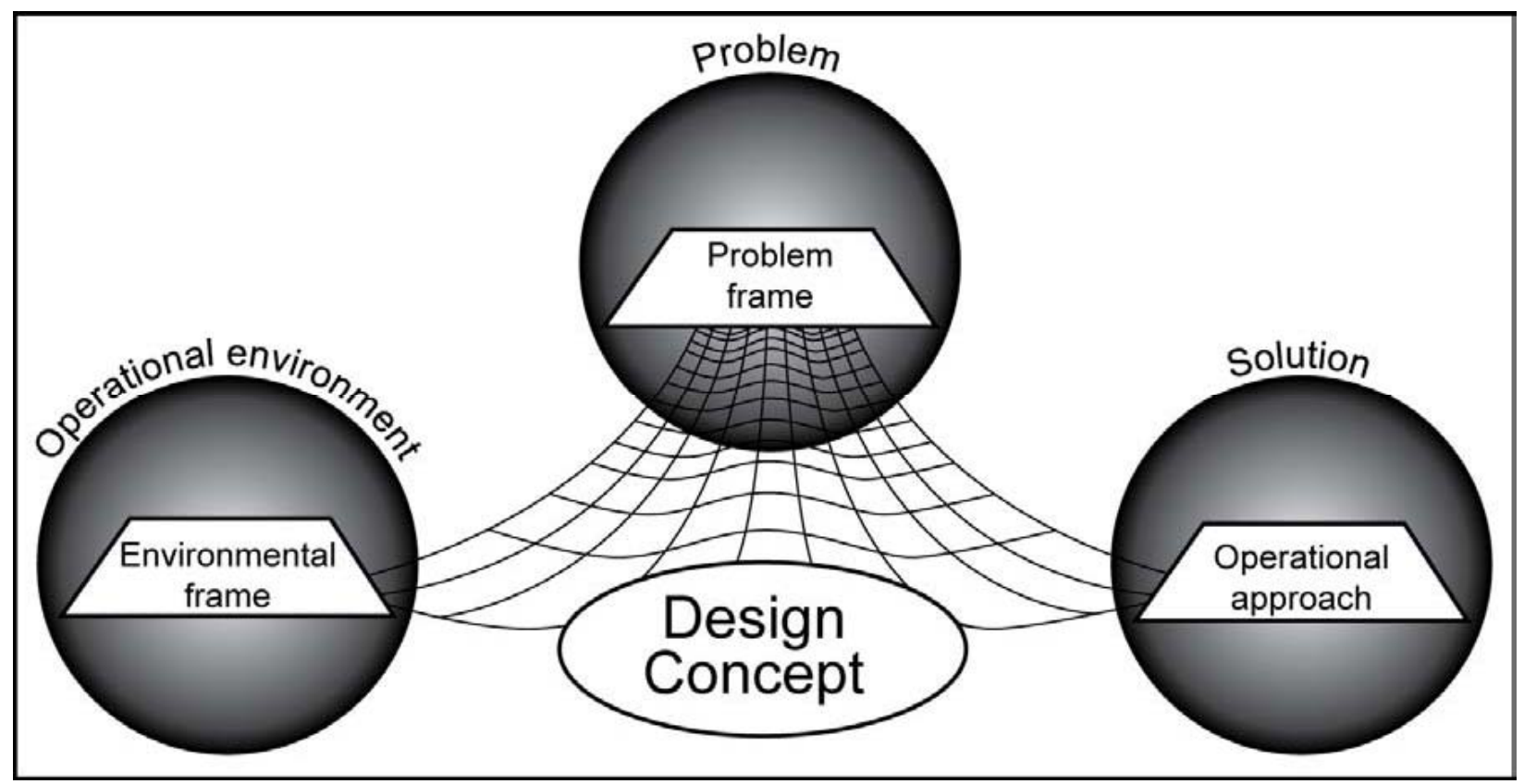

\section{A Complex, Ill-Structured Problem}

When we engage in a pursuit, a clear and precise conception of what we are pursuing would seem to be the first thing we need, instead of the last we are to look forward to.

-John Stuart Mill, The Basic Writings of John Stuart Mill:

On Liberty, The Subjection of Women \& Utilitarianism

What is a complex, ill-structured problem? Oxford Dictionaries provides the following definitions:

- Complex: consisting of many different and connected parts ${ }^{41}$

- Ill: badly, wrongly, or imperfectly ${ }^{42}$

-Structured: constructed or arranged according to a $\operatorname{plan}^{43}$

\footnotetext{
${ }^{40}$ Art of Design Student Text, p. 132

${ }^{41}$ Internet resource located at: http://oxforddictionaries.com/view/entry/m_en_us1234966\#m_en_us1234966 (accessed on 5/10/11)

${ }^{42}$ Internet resource located at: http://oxforddictionaries.com/view/entry/m_en_us1257063\#m_en_us1257063 (accessed on 5/10/11)
} 
- Problem: a matter or situation regarded as unwelcome or harmful and needing to be dealt with and overcome ${ }^{44}$

Adding the definitions together, a complex, ill-structured problem is a badly constructed (and/or planned) situation consisting of many different and connected parts which needs to be dealt with and overcome. According to a Congressional Research Service report, the FBI had many problems on September 12. "The Congressional Joint Inquiry Into the Terrorist Attacks of September 11, 2001, singled out the FBI in a significant manner for failing to focus on the domestic terrorist threat; collect useful intelligence; analyze strategic intelligence; and to share intelligence internally and with other members of the Intelligence Community. The Joint Inquiry concluded that the FBI was seriously deficient in identifying, reporting on, and defending against the foreign terrorist threat to the United States.” ${ }^{\text {45 }}$ The 9/11 Commission takes note of former FBI Deputy Director Robert “Bear” Bryant’s 1998 attempt to mandate a stronger intelligence collection program. Unfortunately, the plan failed on several levels because human resources were not allocated, the new division for strategic analysis lacked high level support, analysts had little access to the information they needed, FBI collection efforts were marked by inadequate training, little source validation, lack of human source production, a shortage of Arabic translators, and information systems rooted in the 1980s. ${ }^{46}$ The failure of Bryant’s program foreshadowed the problems encountered when the Directorate of Intelligence was created; these problems would have been a principal focus of a design approach.

\footnotetext{
${ }^{43}$ Internet resource located at: http://oxforddictionaries.com/view/entry/m_en_us1295059\#m_en_us1295059.005 (accessed on 5/10/11)

${ }^{44}$ Internet resource located at: http://oxforddictionaries.com/view/entry/m_en_us1280894\#m_en_us1280894 (accessed on 5/10/11)

${ }^{45}$ Cumming, Alfred and Masse. Todd, FBI Intelligence Reform Since September 11, 2001: Issues and Options for Congress, Washington, DC, Library of Congress 2004, p. 2

${ }^{46}$ National Commission on Terrorist Attacks Upon the United States (9/11 Commission), The 9/11 Commission Report, Washington, DC 2004, p. 76-77
} 


\section{Recognizing the Problem}

How do you leverage a domestic agency that 80 percent of its resources go to domestic law enforcement, and probably 15 percent to 20 percent of it go to terrorism and counterintelligence? How do you protect America? The FBI's probably the greatest collector of information in the world. But its analysis and dissemination needs a lot of help, needs money... But the thing that was needed was really an analysis in automation. You're trying to fight an international fight on information systems that were 10-12 years old. We reorganized the FBI in 1999. We made counterintelligence and counterterrorism the top priority. We created basically a collection mechanism, and it was, frankly, never funded. .. It was put in the back burner somewhere.

Robert M. “Bear” Bryant, PBS Interview, 2002

The FBI’s 1998 recognition of a problem within their intelligence collection program is clear, and the 1998 Strategic Plan attempted to address the problem. Retired FBI executive Steven McCraw, now the State of Texas Director of Public Safety, recognized a number of problems when he was brought to FBI Headquarters to form what eventually became the Directorate of Intelligence. Among the problems were a shortage of qualified analysts, no analytical career path, poor computer systems or links to other agencies, and short-sighted bureaucratic infighting. He viewed the intelligence process from the perspective of an organized crime investigator. McCraw believed that in the history of the FBI, the organized crime program had provided the best model of how to use intelligence to proactively link criminals and their criminal activities. He liked the "Racketeering Enterprise Investigation” concept, in which persons of interest would become the subject of an intelligence investigation, and agents would seek more information on that person's activities and relationships, while analysts would search files for information and links. ${ }^{47}$

Shortly after McCraw was brought to Headquarters, the FBI Director interviewed National Security Agency executive Maureen Baginski for the position as the FBI’s first Executive Assistant Director for Intelligence. Before accepting the position, Baginski spent two weeks to determine the depth of the FBI’s intelligence program shortcomings. She found no field intelligence structure, even though there were 12,000 collectors (special agents). Limited by Title 5 restrictions, analysts could rise no higher

\footnotetext{
${ }^{47}$ Steven McCraw, interview by author, November 22, 2010
} 
than GS-12 in the field and GS-13 at Headquarters, leading to a significant recruiting and retention problem. If the FBI did recruit a highly skilled analyst, that analyst could receive much more responsibility and compensation outside the FBI, and thus was susceptible to being recruited away. This led to a tendency to promote from within, creating intelligence analysts out of high performing clerks. Baginski was “stunned” by analysts who “couldn’t write a sentence.” The Security Division cleared analysts to Top Secret only by exception. The entire FBI had produced only 34 Intelligence Information Reports in the previous year, and each took an average of a month to release. The analyst training curriculum was "horrible," consisting of "history of the DEA" and "history of the FBI" and similar classes. The FBI was not remotely connected to the requirements process of the intelligence community. Director Mueller himself "was completely focused on the product" going to the Oval Office. After her two week review, Baginski met with the Director and explained the depth of the problem. ${ }^{48}$ The Director committed his support and Baginski accepted the position as FBI Executive Assistant Director for Intelligence, a position she held for the next two years.

\section{FBI Culture and the Environmental Frame}

At its heart, the FBI is a law enforcement agency dedicated to arresting, prosecuting, and convicting people who break the law. FBI agents are very good at law enforcement, but law enforcement isn't intelligence... It keeps information secret rather than getting it to those who can use it to stop the terrorists. The FBI has tried to reform for years, but the bureaucratic resistance is tremendous.

-Senator John Edwards, Address at the Brookings Institution, 2002

Having been assigned to both the Governmental Affairs and Judiciary Committees, Senator Edwards' statement indicates a well-informed understanding of the relationship between FBI culture and the intelligence cycle. His words provide some of the FBI's environmental narrative. The environment and culture of the FBI has developed principally through the efforts of J. Edgar Hoover, who spent 48 years growing the organization. Following Hoover's death in 1972, the FBI went through a series of

\footnotetext{
${ }^{48}$ Baginski, interview
} 
oversight hearings, from the Church Commission in the 1970s, to the WMD Commission in the 2000s. While Hoover shaped the FBI's environment and culture through 1972, the hearings placed dark clouds over the FBI's efforts at domestic intelligence collection, helping to create an environment in which agents and managers avoided involvement in intelligence programs. This was far different from 1939, when Hoover sought and received the mission to fight spies and espionage in the U.S.

The FBI first received its domestic intelligence mission in 1939, when President Roosevelt sent a letter to agencies throughout the U.S.:

The attorney general has been requested by me to instruct the Federal Bureau of Investigation of the Department of Justice to take charge of investigative work in matters relating to espionage, sabotage, and violations of neutrality regulations.

This task must be conducted in a comprehensive and effective manner on a national basis, and all information must be carefully sifted out and correlated in order to avoid confusion and irresponsibility.

To this end I request all police officers, sheriffs, and all other law enforcement officers in the United States promptly to turn over to the nearest representative of the Federal Bureau of Investigation any information obtained by them relating to espionage, counterespionage, sabotage, subversive activities and violations of the neutrality laws. ${ }^{49}$

Prior to 1939 the FBI, then known as the Bureau of Investigation (BI), participated in investigations culminating in the Palmer Raids, a series of arrests targeting "anarchists, Reds and other ultra-left agitators."50 Rather than facing prosecution, many of the arrestees were deported under the 1918 Alien Exclusion Act. These investigations were the result of a series of bombings and attempted bombings in 1919 which targeted the Attorney General, other cabinet members, governors and prominent business magnates John D. Rockefeller and J.P. Morgan. ${ }^{51}$ The Bureau of Investigation had no responsibility for internal security investigations at the time, and had participated in the Palmer Raids under the direction of Attorney General Palmer. According to the FBI’s web site, “The constitutionality of the entire operation was questioned, and Palmer and Hoover were roundly criticized for the plan and

\footnotetext{
${ }^{49}$ Wright, Richard O., Whose F. B. I.?, Open Court, LaSalle, IL 1974, p.142

${ }^{50}$ Wright, p. 144

${ }^{51}$ Don Whitehead, The FBI Story, New York 1956, p. 44
} 
for their overzealous domestic security efforts. The "Palmer Raids” were certainly not a bright spot for the young Bureau. But it did gain valuable experience in terrorism investigations and intelligence work and learn important lessons about the need to protect civil liberties and constitutional rights.”52 In 1924, the new Attorney General, Harlan Fiske Stone, limited "bureau investigations strictly to violations of the law. His new BI director, J. Edgar Hoover, determined that investigations of radicals could not be based on federal statutes and terminated any such operations." 53

The President's 1939 order broadened the FBI’s jurisdiction, not to investigating radicals, but to preventing sabotage like the country had experienced during World War I. At this time, the mission of attack prevention made its debut in the FBI: “Counter sabotage, as distinguished from counterespionage, has been chiefly a preventive operation by the FBI. Arresting a saboteur after the factory door has been unlocked, and the factory itself blown to the high heavens, is a necessary and praiseworthy act; but it does not restore the factory. Hoover's idea is that the owner of the factory should be shown the advisability of bolting the door as well as locking it and of taking many other precautions effectively to bar the saboteur from entering the premises in the first place. So the Bureau prepared, as a result of long study and against a background of long experience in investigating peacetime crimes committed in industrial plants, a booklet of suggestions which proved invaluable to some 25,000 war production executives.”54 Following the war, the FBI's efforts at prevention were minimized as the focus turned to Communists and the Cold War.

During the Cold War period from 1946 to the early 1960s, FBI intelligence efforts were devoted to keeping Communists and their surrogates from committing espionage or undermining the Government. The case involving Julius and Ethel Rosenberg was a typical example of an FBI counterintelligence

\footnotetext{
${ }^{52}$ From the FBI web site, accessed at: http://www.fbi.gov/news/stories/2007/december/palmer_122807 (accessed on $5 / 10 / 11$ )

${ }^{53}$ Wright, p. 156

${ }^{54}$ Collins,Frederick L., The FBI in Peace and War, G.P. Putnam and Sons, New York 1962, p. 47
} 
investigation leading to a series of espionage convictions. ${ }^{55}$ As noted by the Congressional Research Service, "From 1956 through 1971, the FBI conducted an intensive and largely successful domestic security operation to neutralize, among other groups, the Communist Party USA. Since the Party was viewed by many to be under direction of Soviet agents, the FBI considered such investigations to fall under the rubric of the Bureau’s counterintelligence program (hence COINTELPRO). During COINTELPRO, the FBI used wire taps, listening devices, break ins, and other means of covert surveillance - investigative techniques considered legitimate for 'national security’ purposes. Other techniques were more questionable, among those used against civil rights leaders, including Dr. Martin Luther King, Jr. - the leader of the Southern Christian Leadership Conference. The FBI also monitored a wide range of anti-Vietnam war activists. As the line between dissent and sedition blurred, the American public was alarmed by allegations that the FBI was violating the constitutional rights of citizens. ${ }^{56}$ These actions were described by former Director Clarence Kelley as “mistakes of judgment."

Representative Don Edwards, himself a former FBI agent, was the Chairman of the House Judiciary Subcommittee charged with oversight of the FBI. ${ }^{58}$ He took a different view of the FBI's actions during the 1960s and 1970s, noting the FBI’s “frightening litany of Government violations of constitutional rights," and further denounced the concept "that any public official, the President or a policeman, possesses a kind of inherent power to set aside the Constitution whenever he thinks the public interest, or national security warrants it." 59 Several examples of the FBI’s domestic security operations are contained in the Senate Select Committee to Study Governmental Operations with Respect to

\footnotetext{
${ }^{55}$ See http://www.fbi.gov/about-us/history/famous-cases/the-atom-spy-case for a detailed account of the Rosenberg investigation

${ }^{56}$ Masse, Todd and Krouse, William, The FBI: Past, Present, and Future, Congressional Research Service, 2003 p. 6

${ }^{57}$ Testimony of FBI Director Clarence Kelley to the Senate Select Committee to Study Governmental Operations with Respect to Intelligence Activities, December 10, 1975.

${ }^{58}$ Elliff, p. 54

${ }^{59}$ Ibid
} 
Intelligence Activities (Church Committee) Report; for example, during an investigation of “Black Nationalist - Hate Groups, ${ }^{60}$ the St. Louis FBI office drafted and sent the below letter to sow discontent between a husband and wife:

...Look man I guess your old lady dosen't get enougf at home or she wouldn't be shucking and jiving with our Black Men in Action, you dig? Like all she wants to intergrate is the bed room. And us Black sisters aint gonna take no second best from our men... ${ }^{61}$

A later memorandum from the St. Louis FBI indicates the couple "had recently separated following a series of marital arguments...This matrimonial stress and strain should cause her to function much less effectively in ACTION. While the letter sent by the St. Louis Division was probably not the sole cause of this separation, it certainly contributed very strongly." ${ }^{62}$ It is apparent from this and other similar vignettes that the FBI's efforts were to disrupt and undermine organizations, not obtain evidence for prosecution. As noted by Richard Wright, “Cointelpro envisioned no criminal prosecutions of the intelligence targets, but instead involved extra-legal actions designed to deny the target groups their revolutionary aims. This was quite different in principle from the internal security domestic intelligence which J. Edgar Hoover had developed in the 1936-1939 period...”63 Some of these organizations were exercising their First Amendment rights, not committing acts of sedition or violence. Some of the FBI's “mistakes of judgment” resulted from a desire to protect the nation, but others came from the desire to serve the President. In a statement to Congressman Edwards’ Subcommittee, Attorney General Levi noted “that the FBI had been used by Presidents and their White House aides to gather 'political intelligence information during the course of election campaigns and a political convention, as well as to report on

\footnotetext{
${ }^{60}$ Senate Select Committee to Study Governmental Operations with Respect to Intelligence Activities, Volume 6, Exhibit 19-1, accessed at: http://www.aarclibrary.org/publib/church/reports/vol6/pdf/ChurchV6_12_Exhibits.pdf (accessed on 5/10/11)

${ }^{61}$ Ibid

${ }^{62}$ Senate Select Committee to Study Governmental Operations with Respect to Intelligence Activities, U.S. Government, Washington, DC, 1976, Volume 6, Exhibit 19-2

${ }^{63}$ Wright, p.188
} 
activities of critics of administration policies, including members of Congress.”, ${ }^{64}$ On December 3, 1975, a Church Committee staff member detailed additional FBI political abuses dating back to 1940. That statement provides detailed information on wiretaps, surveillance and background checks conducted outside of normal FBI investigations from the 1940s through the Nixon administration, and is included as Appendix 3.

The Church Committee hearings led to the 1976 issuance of the Attorney General’s Guidelines for FBI Domestic Security Investigations, “which established parameters within which it would be permissible for the FBI to conduct investigations into the '...use of force or violence in violation of federal law to overthrow the government or interfere with the activities of a foreign governments within the United States, to substantially impair the federal government in order to influence its policies, or to deprive others of their civil rights.' ... Notwithstanding the abuses of the 1960s, the FBI had many successes in countering espionage activities conducted by U.S. citizens on behalf of the Soviet Union. Some of the higher profile Soviet espionage cases during this decade involved William Kampiles (a CIA employee), Christopher Boyce (an employee of defense contractor TRW, Inc.), and Edwin G. Moore, II (a retired CIA employee).” ${ }^{65}$ The Congressional Research service lists a number of FBI intelligence program successes in the 1980s, but also notes criticism of the FBI's handling of "the Waco and Ruby Ridge sieges, the Oklahoma City bombing documents, the Los Alamos National Laboratory espionage investigation, the Atlanta Olympic Park bombing investigation, the Robert Hanssen spy case, the degradation of the FBI crime lab, the improper use of confidential informants, and the failure to secure and upgrade the agency’s computer systems. The September 11, 2001 attacks, moreover, are widely

\footnotetext{
${ }^{64}$ Elliff, p. 56

${ }^{65}$ Masse and Krouse, p. 7
} 
viewed as a systemic intelligence failure of the U.S. Intelligence Community, of which the FBI is one component." 66

\section{Figure 2: Pre 9/11 FBI Organization Chart $^{67}$}

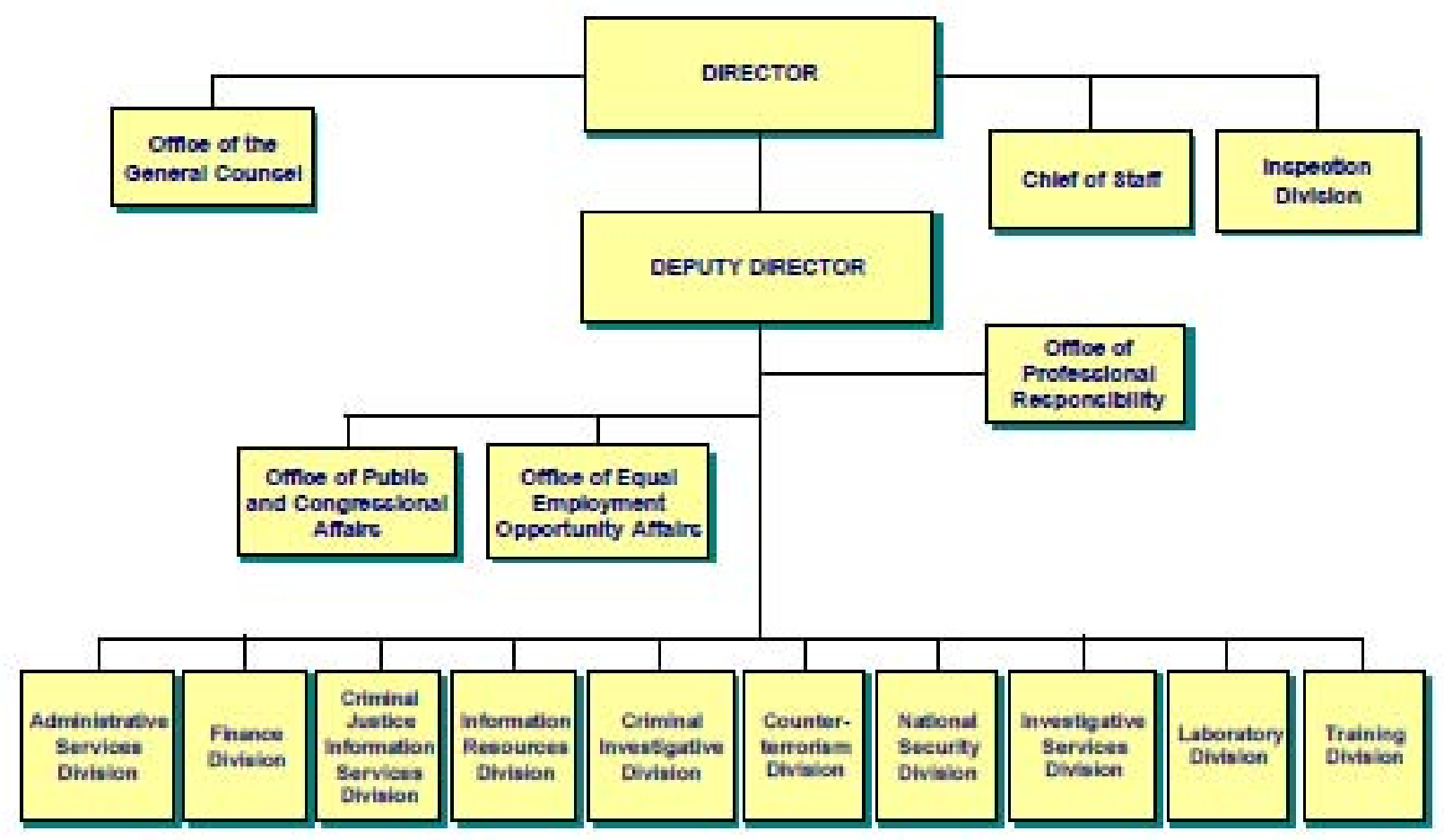

The above chart illustrates the FBI’s organization prior to 9/11. This shows a "flat" organization,

with all operational, support and administrative divisions reporting to the Director and Deputy Director.

There is no separate entity for intelligence collection, analysis, dissemination or coordination.

In her book, Spying Blind: the CIA, the FBI and the Origins of 9/11, author Amy Zegart argues

that: “Agency adaptation failure can be attributed to three enduring realities: (1) the nature of organizations, which makes internal reform exceedingly difficult; (2) the rational self-interests of political officials, which work against executive branch reform; and (3) the fragmented structure of the federal

\footnotetext{
${ }^{66}$ Ibid, p. 2

${ }^{67}$ Copied from Appendix V, Department of Justice Office of the Inspector General Audit Division Audit Report 0439, The Internal Effects of the Federal Bureau of Investigation's Reprioritization, September 2004 (Reprioritization Report)
} 
government, which erects high barriers to legislative reform.”" ${ }^{\circ 8}$ Zegart's argument is demonstrated by the FBI's inability to shift organizational focus to national security and intelligence in the 1998 strategic plan.

In 1998, the FBI issued a five-year strategic plan led by its deputy director, Robert 'Bear' Bryant. For the first time, the FBI designated national and economic security, including counterterrorism, as its top priority. Dale Watson, who would later become the head of the new counterterrorism Division, said that after the East Africa bombings, 'the light came on' that cultural change had to occur within the FBI. The plan mandated a stronger intelligence collection effort. It called for a nationwide automated system to facilitate information collection, analysis, and dissemination. It envisioned the creation of a professional intelligence cadre of experienced and trained agents and analysts. If successfully implemented, this would have been a major step toward addressing terrorism systematically, rather than as individual unrelated cases. ${ }^{69}$

Despite the backing of Director Freeh, Deputy Director Bryant and others, the changes never took root. It wasn’t until after 9/11 that 1200 agents dedicated to criminal investigations, primarily violent crime (bank robbery, fugitives, art theft, kidnaping, property crimes) investigators, were shifted to counterterrorism. $^{70}$ The 9/11 Commission noted that "in 2000, there were still twice as many agents devoted to drug enforcement as to counterterrorism.”, ${ }^{71}$ The new Investigative Services Division (forerunner of the Directorate of Intelligence), created by the 1998 plan to improve the FBI's strategic analysis, did not succeed due to a lack of resources and resistance from senior managers. "The new division was supposed to identify trends in terrorist activity, determine what the FBI did not know, and ultimately drive collection efforts. However, the FBI had little appreciation for the role of analysis. Analysts continued to be used primarily in a tactical fashion-providing support for existing cases. Compounding the problem was the FBI's tradition of hiring analysts from within instead of recruiting

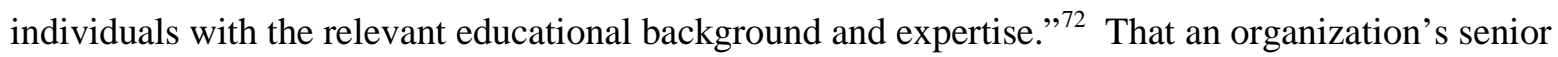
managers could resist and effectively stop the 1998 strategic plan from full implementation is a testament

\footnotetext{
${ }^{68}$ Zegart, Amy, Spying Blind: the CIA, the FBI and the origins of 9/11, Princeton, NJ, Princeton University Press 2007 p.43

${ }^{69}$ 9/11 Commission Report, p. 76

${ }^{70}$ Reprioritization Report, p. 12

${ }^{71}$ 9/11 Commission Report, p. 77

${ }^{72}$ Ibid
} 
to the FBI’s law enforcement culture. Zegart's graphic representation of the FBI’s “Organizational Roots of Failure” has been adapted below:

\section{Figure 3: Pre 9/11 FBI Adaptation Failure ${ }^{73}$}

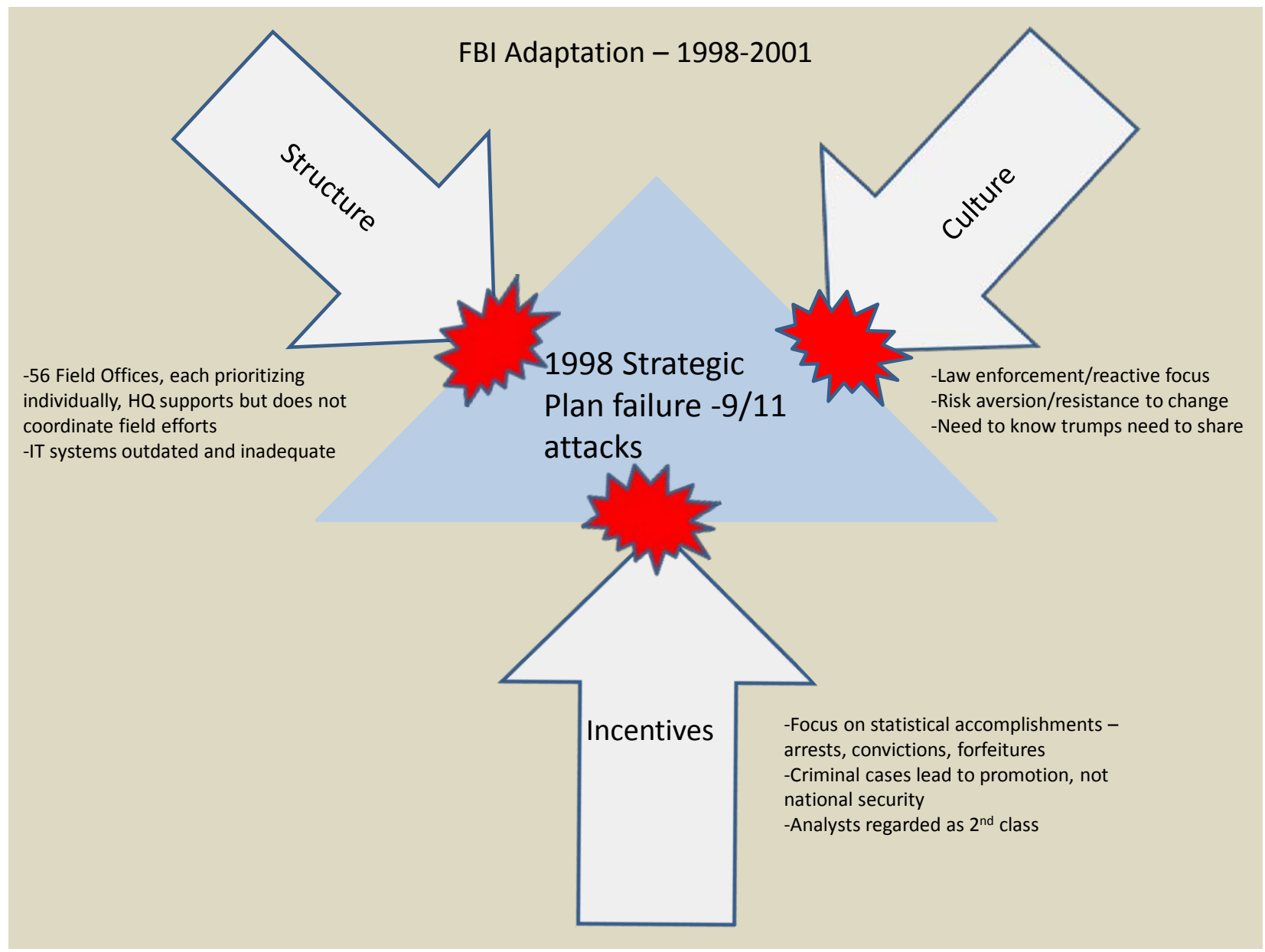

One of the first attempts to force post-9/11 adaptation came in the 2001-2 reorganization of the FBI. The below chart provides the FBI’s organization in March 2004, about ten months after Baginski came to the FBI:

\footnotetext{
${ }^{73}$ The original chart, Figure 6-1 of Zegart's book, can be found on page 122.
} 
Figure 4: FBI Organizational Chart $^{74}$

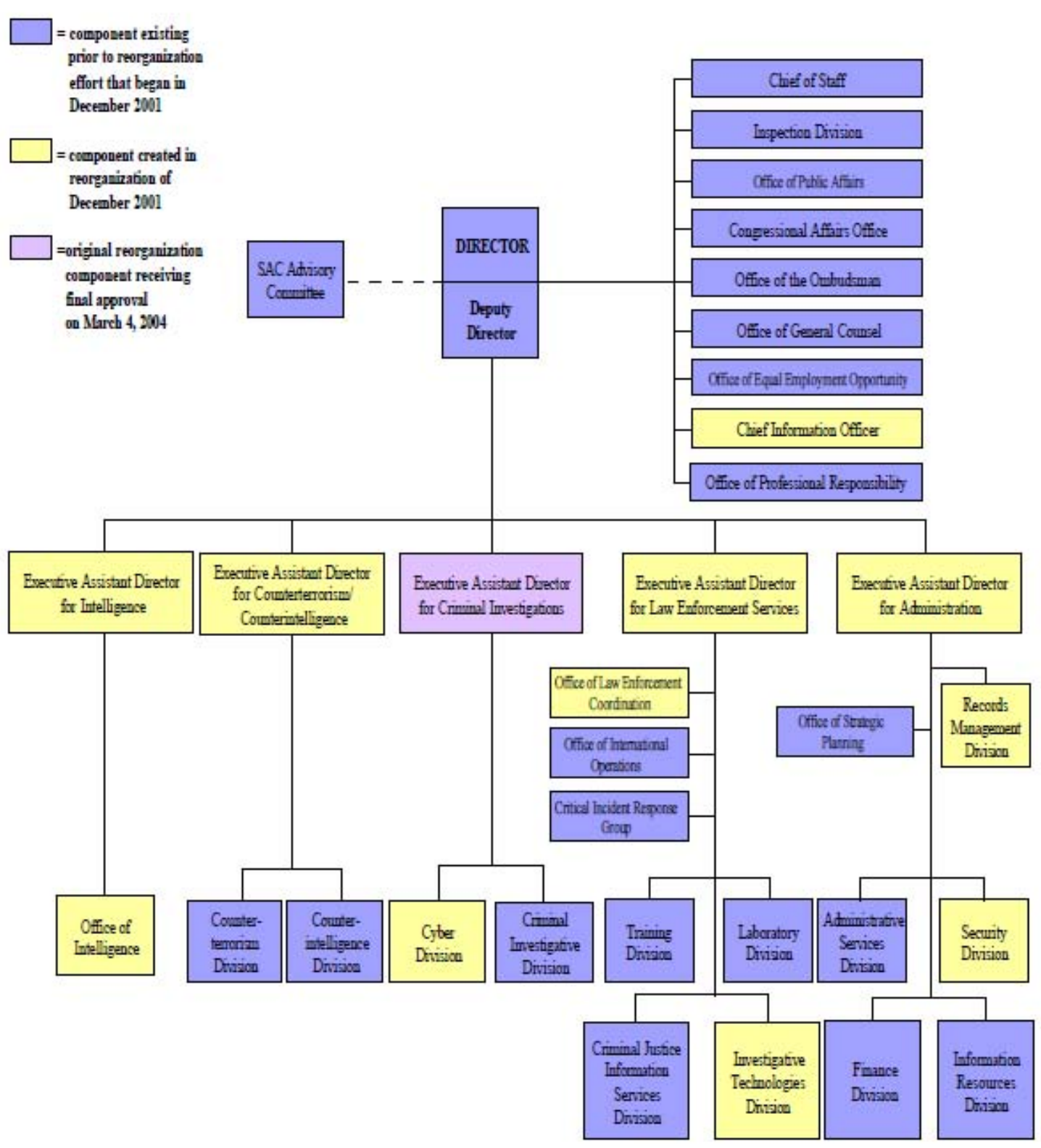

${ }^{74}$ Copied from Appendix IV of the Reprioritization Report 
This chart indicates the Director's placement of the FBI's Executive Assistant Director (EAD) for Intelligence on an equal footing with EADs for Counterterrorism/Counterintelligence, Criminal Investigation, Law Enforcement Services and Administration. As a non-agent from an outside agency given the responsibility to transform the FBI into a domestic intelligence agency, Baginski had a nearly impossible task to accomplish. The task is particularly acute when considering the FBI's long-developed culture as a law enforcement agency, and its previous failure to accept the 1998 Strategic Plan.

FBI history and culture, including both positives and negatives from the past, are principle components of the environmental frame for this problem. The products of environmental framing include a graphic depiction and an environmental narrative. The majority of the initial work in a design problem is conducted in the environmental frame, with smaller groups working in the problem and solution frames. Once the environmental products have been completed, the main effort shifts to the problem and solution frames. ${ }^{75}$

Given the history of FBI accomplishments and shortcomings, the design team can assemble an environmental narrative:

The FBI began in 1908 as the investigative arm of the Department of Justice. Following 16 years as a relatively obscure agency, J. Edgar Hoover was appointed as Director. Over the 48 years of his tenure as Director, the FBI became the leading law enforcement agency in the world, investigating a wide range of crimes, including bank robberies, mail fraud, espionage and terrorism. The FBI motto, "Fidelity Bravery Integrity,” was tarnished by scandals in the 1960s, 1970s, 1980s, and 1990s, and further scarred by intelligence and organizational failures which failed to prevent the 9/11 attacks. The FBI's law enforcement culture prevented implementation of the 1998 Strategic Plan, which attempted to place a

\footnotetext{
${ }^{75}$ Adapted from Art of Design Student Text p. 199
} 
higher value on intelligence and analysts. Since 9/11 the FBI has undergone reforms to transform into an intelligence agency while maintaining its reputation as the world's top law enforcement agency.

\section{Using Design to Frame the Problem}

The mess should be presented as a consequence of past success, not as a result of failure.

-Jamshid Gharajedaghi, Systems Thinking

After many meetings, consultations, briefings and discussions, the problems identified by McCraw and Baginski included: ${ }^{76}$ quality of on board analysts, recruiting and retention of analysts, poor analyst training, poor analyst supervision, poor IT systems, lack of connectivity to other IC agencies, nonsupport from the bureaucracy, lack of intelligence sharing/reporting and timeliness of reports.

The WMD Commission noted additional problems, including a stiff bureaucratic resistance to change at the FBI, a lack of human source validation, and the tendency to treat intelligence analysts like clerks. $^{77}$

The 9/11 Commission noted many of the same problems, but also looked at the FBI’s 1998 attempt to implement a strategic plan mandating a stronger intelligence collection effort. The plan “envisioned the creation of a professional intelligence cadre of experienced and trained agents and analysts.”78 The Commission noted the failure of the 1998 plan resulted from lack of resources and senior manager resistance for the new division created to provide strategic analysis, little appreciation for the analysts' role and the poor state of FBI access to IC information, limited collection from human sources, lack of agent training in national security matters, no method to track or validate human source reporting, lack of translation capabilities, and woefully inadequate information systems. ${ }^{79}$

\footnotetext{
${ }^{76}$ Summarized from the Baginski and McCraw interviews

${ }^{77}$ WMD Commission Report, p. 452

${ }^{78}$ The 9/11 Commission Report, p. 76
} 
A February 2011 report on the Fort Hood shootings from the Senate Committee on Homeland

Security indicated the FBI's continued problem with training and utilizing intelligence analysts:

In the Hasan case, the FBI did not effectively utilize intelligence analysts who could have provided a different perspective given the evidence that it had. The FBI 's inquiry focused narrowly on whether Hasan was engaged in terrorist activity - as opposed to whether he was radicalizing to violent Islamist extremism and whether this radicalization might pose counterintelligence or other threats (e.g., Hasan might spy for the Taliban if he was deployed to Afghanistan). This critical mistake may have been avoided if intelligence analysts were appropriately engaged in the inquiry. Since $9 / 11$, the FBI has increased its intelligence focus by creating a Directorate of Intelligence and Field

Intelligence Groups in the field offices and hi ring thousands of new and better qualified analysts. However, the FBI must ensure that these analysts are effectively utilized, including that they achieve significant stature in the FBI. The FB I must also ensure that all of its agents and analysts are trained to understand violent Islamist extremism. ${ }^{80}$

The Fort Hood report clearly indicates the FBI’s intelligence program has not achieved an appropriate "end state” nearly ten years after the 9/11 attacks. Joint Publication 1-02 defines end state as “The set of required conditions that defines achievement of the commander's objectives.”81

Given the identified problems listed above, how would a design-oriented Director have articulated the end state for the FBI's intelligence programs? First, his objective would be to: Prevent crime through timely collection, analysis and reporting of information from all sources. The required conditions would include:

1) Analysts and agents have timely access to all source information;

2) Analysts and agents are trained on and perform to a high standard on all aspects of the intelligence cycle;

3) Timely translation is available when requested;

4) Analysts routinely provide timely, value-added products;

5) Analysts are retained at the same rate as agents; and

\footnotetext{
${ }^{79}$ Ibid, p 77

${ }^{80}$ Ft Hood Report, “ p. 10

${ }^{81}$ Department of Defense, Joint Publication 1-02 Department of Defense Dictionary of Military and Associated Terms, Washington, DC, 2011
} 
6) Decision makers apply personnel and budgetary resources to threats and gaps identified through products and requirements.

Somewhere between the declared end state and the identified problems above, lies the actual complex, illstructured problem to which design can be applied.

One method used by designers to identify the problem is a directed graph. In this chart, each term is linked to other related terms. The terms with the most links are considered to be critical nodes.

Secondary, tertiary and other important nodes are not regarded as less critical or less important, but rather as items impacted by the critical nodes. For example, "resources" is not a critical node because at any point between 2001 and 2003, the Director could have asked Congress for additional funds and personnel for an intelligence program, and he likely would have received it. One example of Congress’ willingness to assist emanated from EAD Baginski's request to gain FBI exemptions to Title 5, which restricted FBI intelligence analysts to grades 12 and 13. Just three months after the request was made to Congress, an appropriations bill was drafted to include the Title 5 exemption. ${ }^{82}$

${ }^{82}$ Baginski, interview 


\section{Figure 5: FBI Relationships}

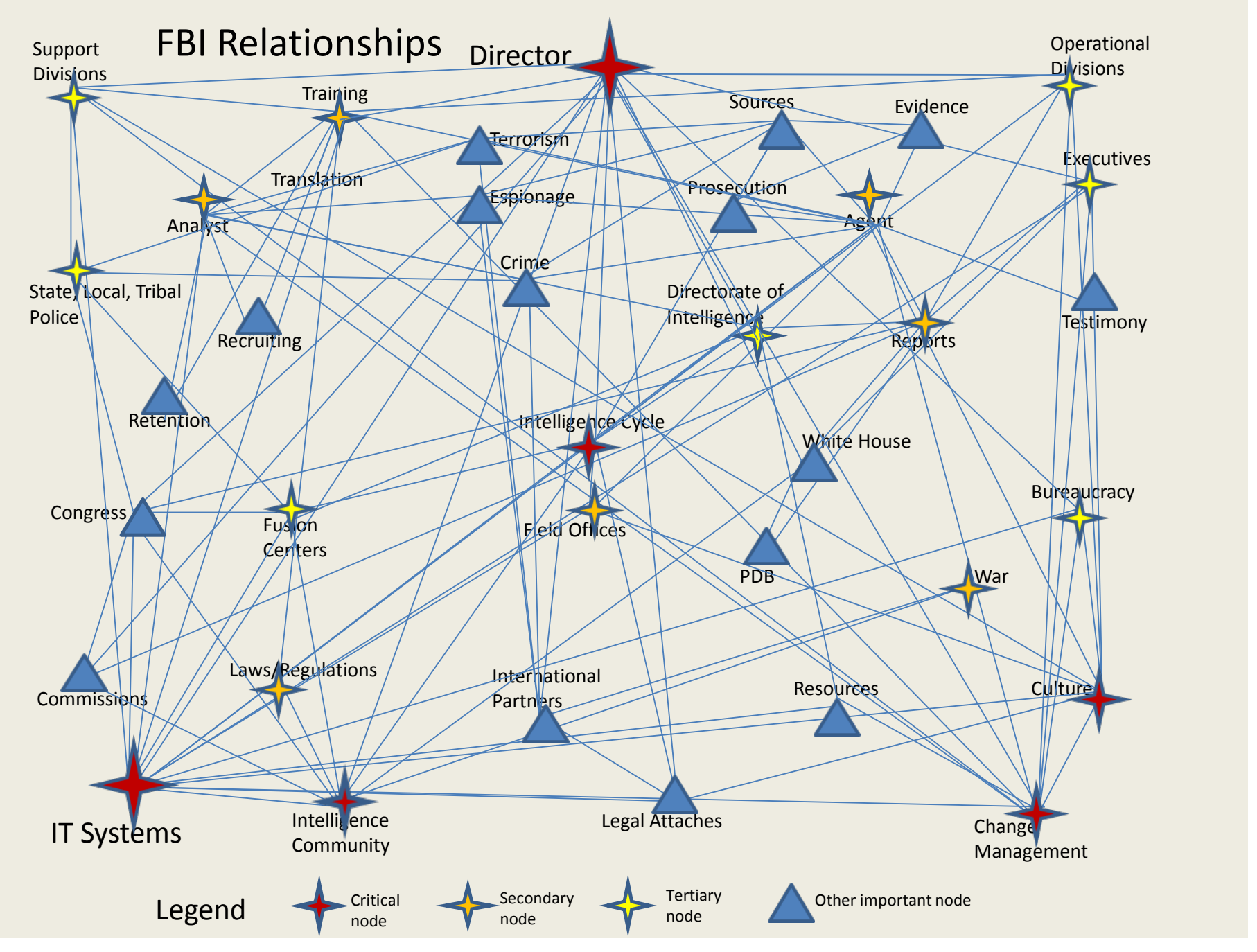

Designers routinely provide visual aids to show relationships, structures, tensions, and other helpful graphics. A diagram providing a graphic display of the tensions involved in this case could be demonstrative of the problem frame and helpful to the solution team. The environmental frame has provided a series of issues identified by commissions, authors and the FBI itself, and the problem team could form those issues into a Problem Tensions diagram: 


\section{Figure 6: Problem Tensions}

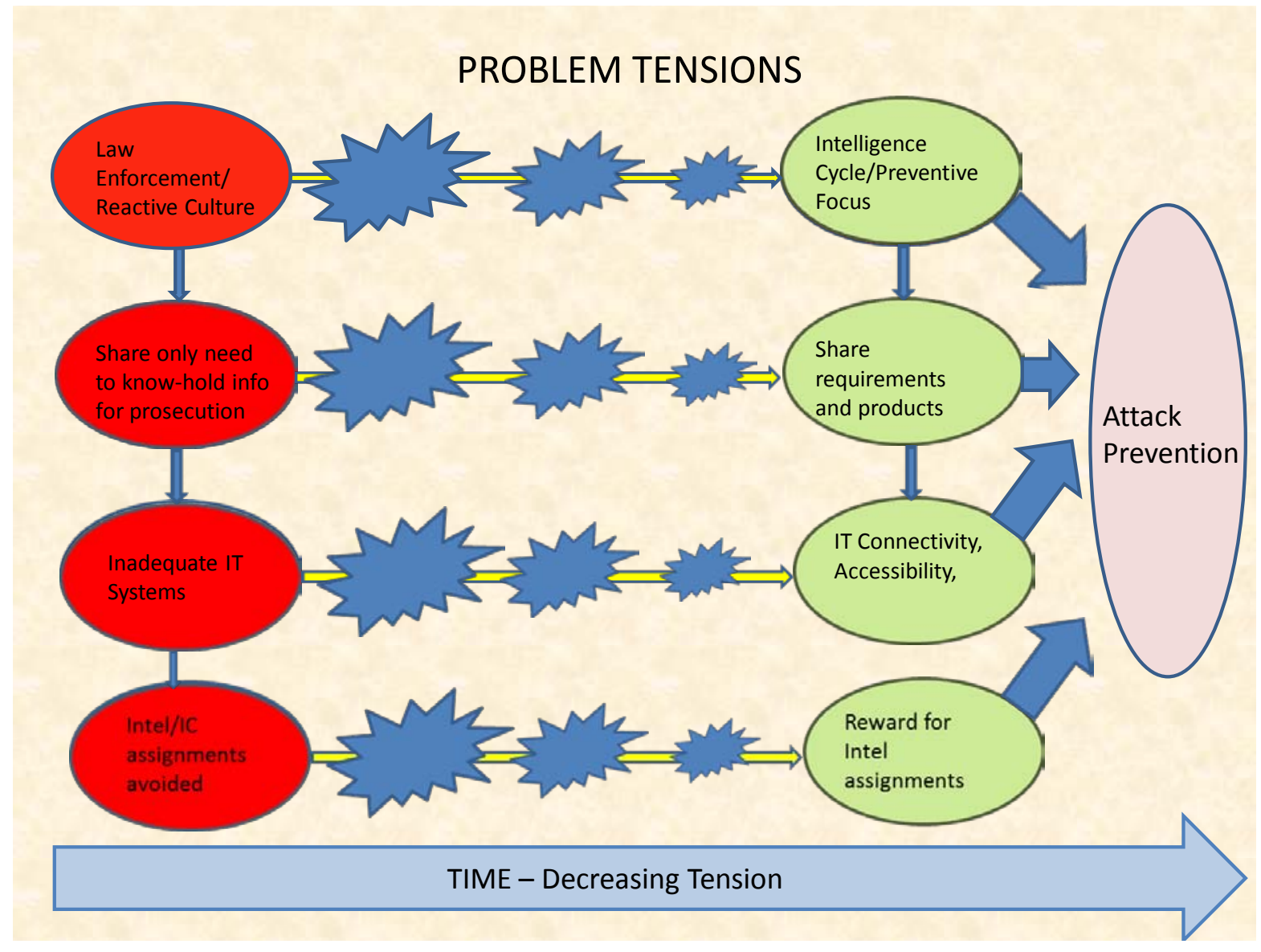

In this diagram, the left side is the FBI's state on 9/12, and the right side is the desired state.

Between the two states is the tension created by the move to an intelligence based organization.

The FBI Relationships diagram, the Problem Tensions diagram, 9/11 Commission Report and other information sources discussed in the above paragraphs serve as input for the problem statement, which "broadly describes the requirements for transformation, anticipating changes in the operational environment while identifying critical transitions." 83 In the design process, a group of FBI and non-FBI personnel would identify the elements of the problem, identify key nodes and draft a problem statement that clearly defines the problem. The statement would also provide guidance on transforming the current conditions to the desired end state. In this case, the end state (notionally) declared by the Director is:

\footnotetext{
${ }^{83}$ Art of Design Student Text, p. 138
} 
Objective: Prevent terrorism, espionage and crime through timely collection, analysis and reporting of information from all sources.

\section{Required conditions:}

1) Analysts and agents have timely access to all source information;

2) Analysts and agents are trained on and perform to a high standard on all aspects of the intelligence cycle;

3) Timely translation is available when requested;

4) Analysts routinely provide timely, value-added products;

5) Analysts are retained at the same rate as agents; and

6) Decision makers apply personnel and budgetary resources to threats and gaps identified through products and requirements.

Based on this end state, the problem statement would be:

The FBI collects a wide range of information from many sources. This information is not easily disseminated to, or assimilated and processed by well trained, experienced BI analysts. Difficulties in dissemination, assimilation and processing are caused by inadequate IT systems, lack of translation capability, lack of knowledge of intelligence requirements and processes, poor analyst training, lack of experienced analysts, and lack of an intelligence culture within the FBI. Given the problems in providing collected information to experienced and trained analysts, the FBI is not capable of conducting appropriate information analysis and providing subsequent analytical products. 


\section{Framing the Solution}

There are an inexhaustible number of different solutions...it seems unreasonable to expect that we can be sure that all the solutions to a problem have been identified.

-Bryan Lawson, How Designers Think

Viewing the Directorate of Intelligence through the lens of a design process provides six key nodes identified in the FBI Relationships chart, Figure 5. Those nodes are the FBI Director, the Intelligence Cycle, Change Management, FBI Culture, the Intelligence Community, and IT Systems. When those nodes are applied to the problems identified in the FBI Adaptations diagram, Figure 7, the End State diagram, Figure 8, and the Problem Tensions diagram above, a solution begins to form. In How Designers Think, Lawson describes four "generators of design constraints," ${ }^{84}$ the designer, the client, the user and the legislator. In our case, the designer is the group leading the design, the client is the American public, the user is the FBI and the rest of the Intelligence Community, and the legislator is the Congress and the Constitution. The designer may produce a solution guaranteed to succeed, but that solution might overstep the constraints of the legislator, or it may involve so much money that the client has to apply constraints to the budget. Ultimately the solution is a reconciliation between the problem view, which is expressed as needs, desires, wishes and requirements, and the solution view, expressed in this case as funding, systems, and leadership. ${ }^{85}$

\footnotetext{
${ }^{84}$ Lawson, p. 91

${ }^{85}$ Lawson, p. 272
} 
Figure 7: FBI Adaptation - Using Design

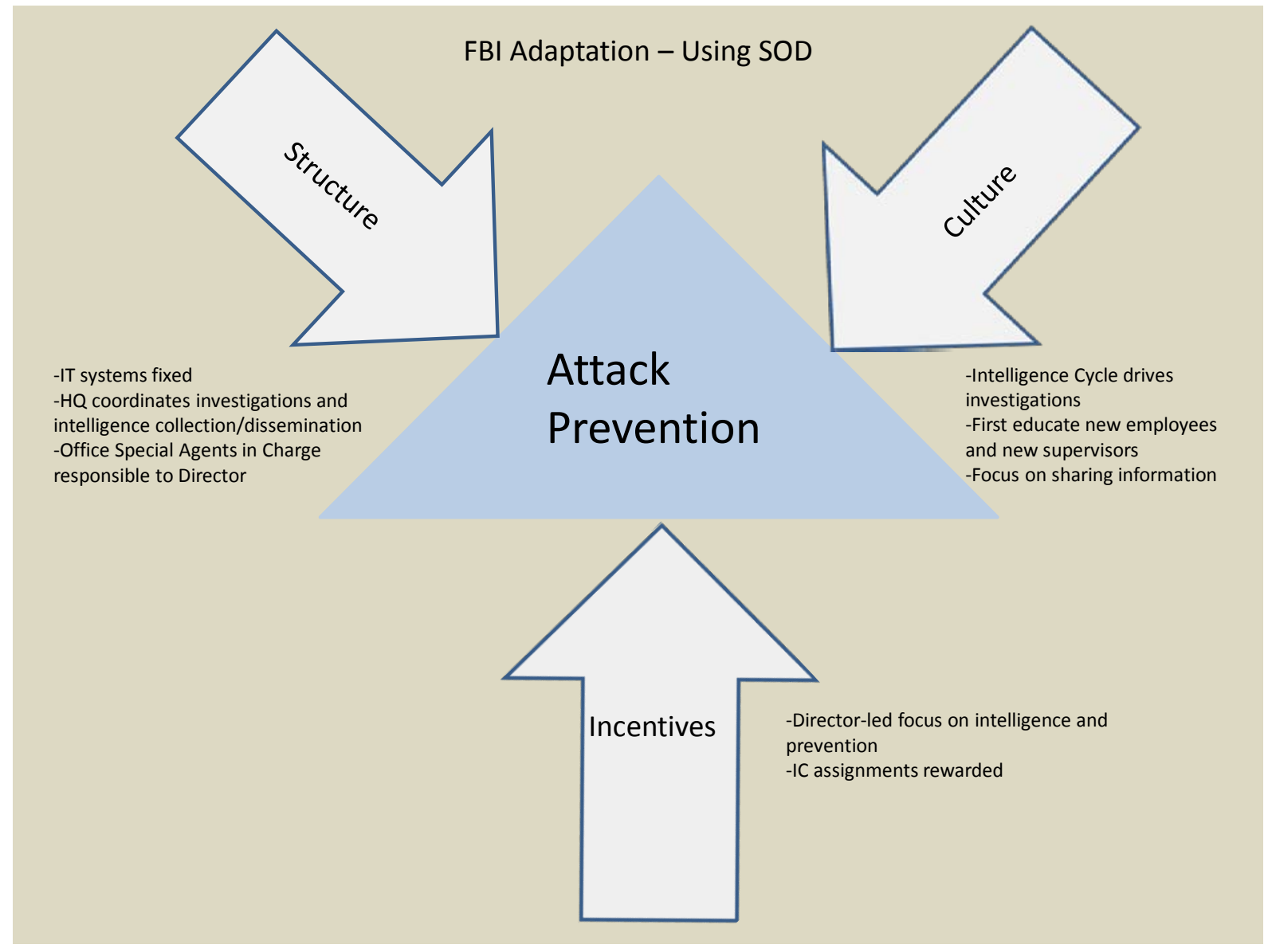

This adaptation diagram applies new end states to the three basic FBI inputs, structure, culture and incentives. If applied holistically, using a comprehensive approach, the FBI can reach the Director's notional intelligence end state: Prevent terrorism, espionage and crime through timely collection, analysis and reporting of information from all sources. 
Figure 8: FBI Intelligence - 9/12 to End State

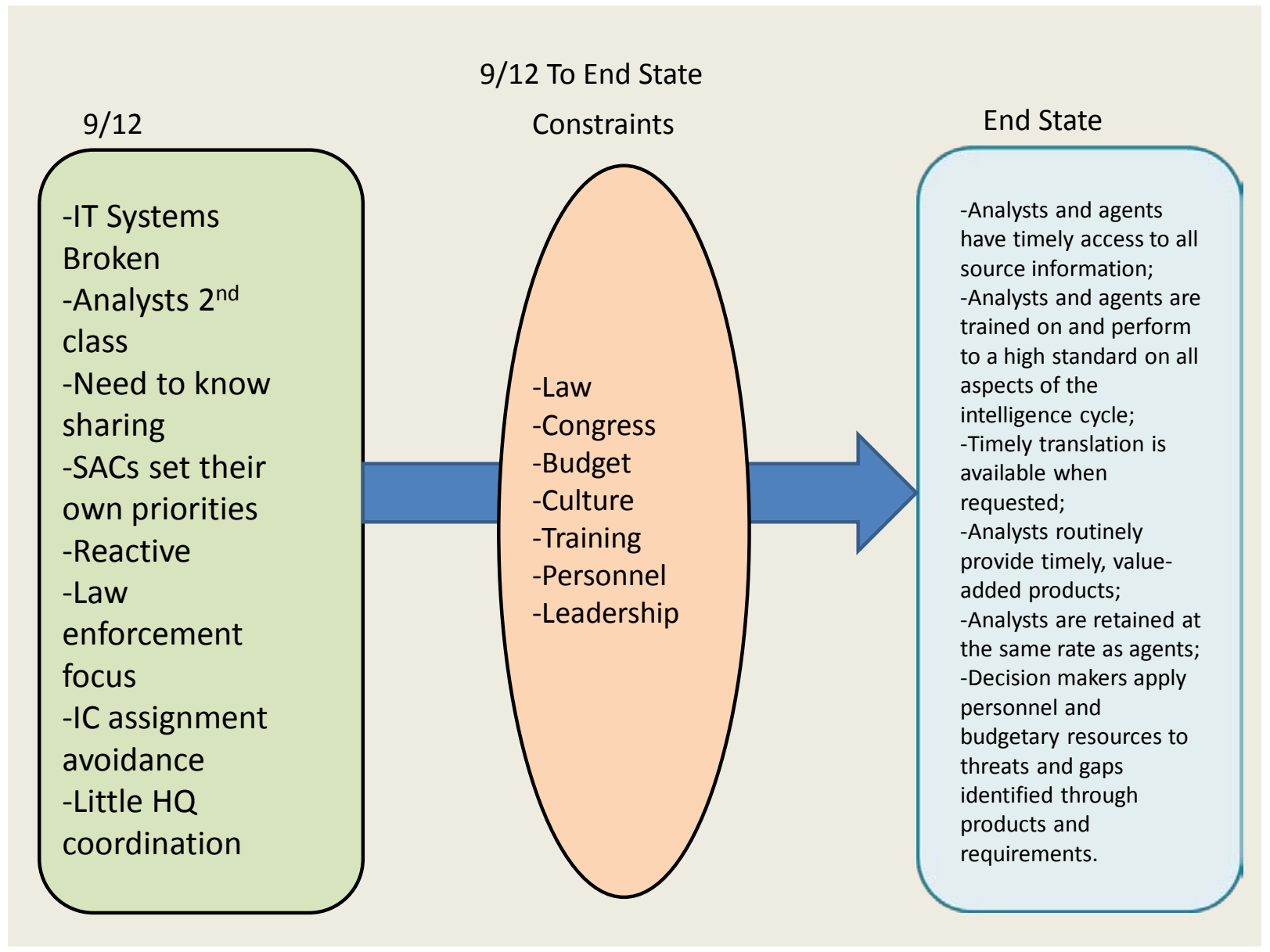

This diagram represents the FBI Intelligence Program as it existed on 9/12, the constraints against changing the Program, and the Director's notional end state. In 2003, newly appointed EAD Baginski set out to resolve the same issues, using her own experience at the NSA as a guide, believing the FBI needed a G-2-like entity. With Deputy Assistant Director McCraw’s added input that the FBI Intelligence Program worked best within the context of a typical racketeering investigation ${ }^{86}$, they began work on a ten week initiative to produce concepts of operation for a framework to improve each of nine core intelligence functions defined by the FBI:

- Community Support

- FBI Intelligence Assessment Process

${ }^{86}$ Baginski and McCraw interviews 
- FBI Intelligence Requirements and Collection Management Process

• FBI Field Office Intelligence Operations

- Forecasting Intelligence Program Operational Requirements

- Human Talent for Intelligence Production

- Integrated Information Sharing

- Intelligence Production and Use

- Intelligence Program Budget Formulation Process ${ }^{87}$

Ideally, it is preferable to conduct detailed planning like this in parallel with conceptual planning.

As noted in FM 5-0:

Planning consists of two separate, but closely related components: a conceptual component and a detailed component. The conceptual component is represented by the cognitive application of design. The detailed component translates broad concepts into a complete and practical plan. During planning, these components overlap with no clear delineation between them. As commanders conceptualize the operation, their vision guides the staff through design and into detailed planning. Design is continuous throughout planning and evolves with increased understanding throughout the operations process. Design underpins the exercise of battle command, guiding the iterative and often cyclic application of understanding, visualizing, and describing. As these iterations occur, the design concept - the tangible link to detailed planningis forged. ${ }^{8}$

In our case, there were dedicated and experienced personnel working through detailed planning to transform the FBI’s Intelligence Program. The Director had little experience in the intelligence field and relied on their efforts. The Program succeeded in some areas, but the 2009 Fort Hood shootings tragically symbolized that much remains to be done. If design had been available to these planners, the need for cultural transformation may have been approached differently, and the Intelligence Program's acceptance may have been accelerated.

\footnotetext{
${ }^{87}$ Department of Justice, The Federal Bureau of Investigation's Efforts to Improve the Sharing of Intelligence and Other Information, Washington, DC 2003

${ }^{88}$ FM 5-0, p. 3-1
} 


\section{The Iterative Process}

Since design problems defy comprehensive description and offer an inexhaustible number of solutions, the design process cannot have a finite and identifiable end. The designer's job is never really done and it is probably always possible to do better.

-Bryan Lawson, How Designers Think

Lawson's statement is clearly valid when considering our definition of a complex, ill-structured problem: a badly constructed (and/or planned) situation consisting of many different and connected parts which needs to be dealt with and overcome. According to the SAMS Art of Design Student Text, “perhaps the most fundamental technique of design is reflection.” ${ }^{89}$ Donald Schön breaks down reflection into two types, reflection in action and reflection on action. ${ }^{90}$ When doing a routine task and something unexpected occurs, one may stop to determine what is hindering the task - that is reflection in action. Once you have completed a task and think about how to do it better - that is reflection on action. In the FBI Intelligence Program, one output is an Intelligence Information Report (IIR). As noted above, in 2002 the FBI produced only 34 intelligence products, including IIRs, and each took an average of a month to be approved and disseminated. If a design approach had been implemented in 2003, intelligence products would have been the subject of much iteration and reflection. Both the quantity and speed of production would be examined and reflected upon to determine why the quantity and timing were inadequate. Intelligence production is only one aspect of the complex, ill-structured problem contained within the larger problem of the FBI’s Intelligence Program, but iteration and reflection by teams in the environmental, problem and solution frames could result in this as one of the focal points of the Program's design, i.e. if you solve this problem, you will have already dealt with many other problems.

\footnotetext{
${ }^{89}$ Art of Design, p. 171

${ }^{90}$ Schön, Donald, Educating the Reflective Practioner, San Francisco, Jossey-Bass, 1987, p 26
} 


\section{Leadership and Design}

The FBI is one of the proudest and most independent agencies in the United States Government. It is on its way to becoming an effective intelligence agency, but it will never arrive if it insists on using only its own map.

-WMD Commission Report

One of the key components of successful design is the commander. As noted in FM 5-0, "the more complex a situation is, the more important the commander's role is in design." 91 The commander assembles the design team and sets the tone for iterative collaboration. A team should be selected based on experience, subject matter expertise, and their capability to produce expert knowledge from other areas. A design-oriented commander understands that previous solutions will not fit new problems, and leads innovative and adaptive efforts toward new solutions and adaptation when situations change. ${ }^{92}$ In the example of designing a post 9/11 FBI Intelligence Program, the Director appointed a career Intelligence Community executive, as his intelligence experience was limited. If that executive had the benefit of design, the FBI’s Intelligence Program development would have taken a different form, emphasizing environment, collaboration and iteration over the bureaucratic processes she was familiar with.

\section{Preparing the FBI for Design}

While the organization as a whole is becoming more and more interdependent, its parts increasingly display choice and behave independently. The resolution of this dilemma requires a dual shift of paradigm. The first shift will result in the ability to see the organization as a multiminded, sociocultural system, a voluntary association of purposeful members who have come together to serve themselves by serving a need in the environment. The second shift will help us see through chaos and complexity and learn how to deal with an interdependent set of variables. Failure to appreciate the significance of this dual change results in excessive structural conflict, anxiety, a feeling of impotency, and resistance to change.

\footnotetext{
${ }^{91}$ FM 5-0 p. 3-6

${ }^{92}$ Much of this paragraph is summarized from FM 5-0, page 3-6
} 
Lieutenant General George Flynn, in a meeting with SAMS Fellows in March 2011, commented that the Marine Corps had not been very interested in design until General Mattis pushed the concept, and through his leadership began assembling others who saw its advantages and together brought design into their doctrine. ${ }^{93}$ Given the FBI’s bureaucratic culture and history of inaction on the 1998 Strategic Plan, it may be difficult to convince executives that design is a concept worth considering for a wide variety of complex, ill-structured problems. As noted above, there are some in the FBI who have already intuitively applied design to complex, ill-structured problems and succeeded. Those problems and their subsequently designed organizational solutions can be highlighted to demonstrate the value of design. There are many other examples in which the FBI's traditional methods of problem solving led to significant failures and wasteful spending. ${ }^{94}$ Ultimately, it took someone with the stature and leadership of General Mattis to bring design to the Marine Corps, and it will take a similar personality to do the same for the FBI. Perhaps the federal budget crunch and the resulting loss of contractors will cause the FBI to look at problems differently, and in seeking new methods, will come across design. Whether through the influence of a strong personality or through a crisis, use of design will need to be preceded by education and practical problem solving exercises.

\section{Conclusion}

To succeed, we must update, balance, and integrate all of the tools of American power and work with our allies and partners to do the same. .. Our intelligence capabilities must continuously evolve to identify and characterize conventional and asymmetric threats and provide timely insight. And we must integrate our approach to homeland security with our broader national security approach. We are improving the integration of skills and capabilities within our military and civilian institutions, so they complement each other and operate seamlessly. We are also improving coordinated planning and policymaking and must build our capacity in key areas where we fall short. This requires close cooperation with Congress and a deliberate and inclusive interagency process, so that we achieve integration of our efforts to implement and monitor operations, policies, and strategies.

\footnotetext{
${ }^{93}$ LtGen Flynn, USMC, comments to AOASF Fellows on March 14, 2011

${ }^{94}$ Although not addressed in this monograph, the FBI spent over $\$ 170$ million to develop Virtual Case File, a system which never progressed beyond initial testing. The problems in this program, as documented by the Department of Justice Inspector General, could have been addressed by a design process and saved both money and time while creating efficiencies within the FBI.
} 
The attacks of September 11, 2001 affected the lives of all Americans and demonstrated the need for a better intelligence program at the FBI. The FBI's history and culture are dominated by excellence in law enforcement, and from the time of the Church Committee hearings in the 1970s until 9/11, the FBI's Intelligence Program was neglected. On September 12, 2001, the transformation of the FBI began, but as seen in the Senate report on the Fort Hood shootings, the FBI Intelligence Program’s transformational pace has been too slow. Had design been available to the executives assigned to plan the Program, culture and other key factors would have been emphasized in the transformation, creating the opportunity for more rapid acceptance and assimilation of the Intelligence Program’s processes and goals (which were created through their detailed planning process). Design can be applied to any complex, ill-structured problem. In the above quote from the National Security Strategy, the President used words like update, balance, integrate, evolve, insight, coordinate, cooperate, inclusive and interagency. These words could have been taken directly from a guide to design. Given the President's guidance and the many complex, ill-structured problems facing the FBI, design should be considered for FBI development and application. As demonstrated in this paper, timely application of design to the FBI's Intelligence Program would have shown the need to emphasize cultural transformation while implementing intelligence policy and procedural changes, creating the potential for acceleration of the FBI's transformation, lives saved and terrorist attacks prevented. 


\section{Appendix $1^{95}$}

\section{FBI Intelligence Programs}

The FBI and its predecessor, the Bureau of Intelligence, have collected intelligence — foreign intelligence, counterintelligence and criminal intelligence - in the U.S. since 1908, and, at times, effectively. During the Cold War, the FBI successfully penetrated the Soviet leadership through a recruited U.S. Communist Party asset. The FBI also battled the Kremlin on the counterintelligence front. In 1985 - dubbed the Year of the Spy, the FBI arrested 11 U.S. citizens for espionage, including former U.S. warrant officer John Walker, who provided the Soviets highly classified cryptography codes during a spying career that began in the 1960s. The FBI also arrested Larry Wu-Tai Chin, a CIA employee, a spy for the People's Republic of China; Jonathan Pollard, a Naval Investigative Service intelligence analyst who stole secrets for Israel; and Ronald Pelton, a former National Security Agency communications specialist who provided the Soviet Union classified material. More recently convicted spies include FBI Special Agent Robert P. Hanssen, who spied on behalf of Soviet Union and, subsequently, Russia, and pleaded guilty to 15 espionage-related charges in 2001; and former Defense Intelligence Agency analyst Ana Belen Montes, arrested in 2001 and subsequently convicted for spying for Cuba.

\section{FBI Excesses}

The FBI has been applauded for its historical successes, but also criticized for overstepping constitutional bounds by targeting U.S. citizens who were found to be exercising their constitutional rights. For example, during the 1919-1920 “Palmer Raids,” the FBI’s so-called Radical Division (later renamed the General Intelligence Division) arrested individuals allegedly working to overthrow the U.S. government, but who were later judged to be innocent. Between 1956 and 1970, the FBI investigated individuals it believed were engaging in "subversive" activities as part of the FBI's so-called COINTELPRO Program. In the mid-1960s, the FBI surveilled such prominent Americans as Martin Luther King, Jr., collecting "racial intelligence.” And in the 1980s, the FBI was found to have violated the constitutional rights of members of the Committee in Solidarity with the People of El Salvador (CISPES) who the FBI believed violated the Foreign Agent Registration Act. Although congressional investigators concluded that the FBI's investigation did not reflect "significant FBI political or ideological bias ...," its activities "resulted in the investigation of domestic political activities protected by the First Amendment that should not have come under governmental scrutiny."

\footnotetext{
${ }^{95}$ Cumming, Alfred and Masse. Todd FBI Intelligence Reform Since September 11, 2001: Issues and Options for Congress, Washington, DC: Library of Congress 2004
} 


\section{Appendix $2^{96}$}

\section{Evolution of FBI Intelligence}

The FBI has always used intelligence to investigate and solve cases. Throughout the Bureau's history, our ability to successfully adapt to new threats included the development of increasingly sophisticated methods of gathering, analyzing, and disseminating intelligence. Information about the FBI's history and its intelligence role from its founding through the 1990s may be found on the FBI history page.

It was in the aftermath of the events of 9/11 that the FBI recognized the need to establish centralized control over intelligence operations throughout the Bureau. We began in 2001 with a dedicated analysis section in the Counterterrorism Division (CTD), and in 2002 we created an Office of Intelligence within CTD. This structure and capability significantly enhanced our counterterrorism operations and those of our partners.

In 2003, we extended this concept across all FBI programs-Criminal, Cyber, Counterterrorism, Counterintelligence - and unified intelligence authorities under a new FBI Office of Intelligence led by an executive assistant director for intelligence (EAD-I). The Office of Intelligence leveraged U.S. Intelligence Community tradecraft to direct all FBI intelligence activities. Congress and the National Commission on Terrorist Attacks Upon the United States ("The 9/11 Commission") reviewed these efforts and provided recommendations to further strengthen the FBI's intelligence capability.

The FBI was first directed to create a Directorate of Intelligence through a November 23, 2004 Presidential Memorandum for the Attorney General (titled "Further Strengthening Federal Bureau of Investigation Capabilities") and later through The Consolidated Appropriations Act of 2005. The Intelligence Reform and Terrorism Prevention Act of 2004 reiterated this guidance and formally acknowledged the significant progress made by the FBI in improving its intelligence capabilities since the 9/11 terrorist attacks.

The Directorate of Intelligence was established in February 2005 as a dedicated national intelligence workforce within the FBI-a service within a service. The central mission of the FBI's Intelligence Program is to optimally position the FBI to meet current and emerging national security and criminal threats. We do this in cooperation with our fellow intelligence organizations.

In June 2005, the president directed the attorney general to create a "National Security Service" within the FBI, as recommended by the Commission on the Intelligence Capabilities of the United States Regarding Weapons of Mass Destruction (WMD Commission).

The attorney general implemented the president's directive in September 2005 by creating the FBI's National Security Branch (NSB), which combines the missions, capabilities, and resources of the Counterterrorism and Counterintelligence divisions and the Directorate of Intelligence under the leadership of a senior FBI official. In July 2006, the newly created FBI Weapons of Mass Destruction Directorate (WMDD) also became part of the NSB. The NSB oversees the national security operations of these four components and is accountable for the national security functions carried out by other FBI divisions.

\footnotetext{
${ }^{96}$ FBI Internet resource located at: http://www.fbi.gov/about-us/intelligence/evolution
} 


\title{
Appendix $3^{97}$
}

\section{John Elliff Statement}

\author{
STATEMENT OF JOHN ELLIFF, PROFESSIONAL STAFF MEMRER, \\ SENATE SELECT COMMITTEE TO STUDY COVERNMENTAL OPERATIONS
}

WITH RESPECT TO INTELLIGENCE ACTIVITIES

Mr. ELLIFF. Thank you, Senator Tower.

The political abuse of the FBI and by the FBI did not begin in the 1960's. Although this committee has concentrated its investigations on the events of the 1960s and 1970's, the story cannot be fully understood by looking at just the last 15 years. Therefore, the first objective of this report is to lay out some of the historical context for more recent political abuses of the FBI. The second objective is to describe some of the results of our investigation which show the various types of political abuse to which the FBI is susceptible. Some have been in response to the desires of the Bureau's superiors. Others have been generated by the Bureau itself. And there is the added possibility, suggested by some of the documents we have seen and some of the witnesses we have interviewed, that, certain political abuses resulted from the inexorable dynamics of the FBI's intelligence-gathering system itself. In other words, that the FBI intelligence system developed to a point where no one inside or outside the Bureau was willing, or able, to tell the difference between legitimate national security and law enforcement information and purely political intelligence. Whether any particular abuse resulted from outside demands, from the Bureau's own desires, or from the nature of the intelligence process is a question for the committee to answer when all the evidence is in. The historical background of political abuse of the FBI involves at least three dimensions. The first is the Bureau's subservience to the Presidency, its willingness to carry out White House requests without question. When L. Patrick Gray, as Acting FBI Director, destroyed documents and gave FBI reports to Presidential aides, whom the FBI should have been investigating after the Watergate break-in, he just carried to the extreme an established practice of service to the White House. The other side of this practice was the Bureau's volunteering political intelligence to its superiors. in response to no specific request. The third historical dimension was the FBI's concerted effort to promote its public image and discredit its critics.

Early examples of the Bureau's willingness to do the Presidents' bidding occur under Franklin D. Roosevelt. Materials here are found in exhibit, 34.l In 1940, the Bureau complied with a request to run name checks, open files, and make reports on hundreds of persons who sent telegrams to the President that were-to quote the letter from the President's secretary to J. Edgar Hoover-“all more or less in opposition to national defense,” or that expressed approval of Col. Charles Lindbergh's criticism of the President. Another example, from the Truman period, came to light in recent years when Maj. Gen. Harry Vaughn, President Truman's military aide, disclosed that President Roosevelt had ordered wiretaps on the home telephones of his closest aides. Shortly after Mr. Truman had taken office, someone had presented General Vaughn with transcripts of the wiretaps. He took them to President Truman who said, according

\footnotetext{
${ }^{97}$ Senate Select Committee to Study Governmental Operations with Respect to Intelligence Activities, Volume 6, Statement of John Elliff, accessed at: http://www.aarclibrary.org/publib/church/reports/vol6/pdf/ChurchV6_5_Elliff.pdf
} 
to General Vaughn, “I don’t have time for that foolishness.” This story is generally confirmed by the committee staff's examination of J. Edgar Hoover's "Official and Confidential” files, where an index to the logs of these wiretaps on President Roosevelt's aides was located.

Historical illustrations of the FBI's practice of volunteering political intelligence to its superiors appear in virtually every administration. President Roosevelt's Attorney General, Francis Biddle, recalled in his autobiography how J. Edgar Hoover shared with him some of the "intimate details" of what his fellow Cabinet members did and said, "their likes and dislikes, their weaknesses and their associations." Attorney General Biddle confessed that he enjoyed hearing these derogatory and sometimes "embarrassing” stories and that Director Hoover "knew how to flatter his superior."

President Truman and his aides received regular letters from Hoover, labeled "Personal and Confidential" and containing tidbits of political intelligence. Copies of many of these letters which the committee obtained from the Truman Library, are contained in exhibit 35.2

These letters sometimes reported on possible Communist influence behind various lobbying efforts, such as activities in support of civil rights legislation. They reported allegations that a Communist sympathizer had helped write a Senator's speech. Some of the letters were undoubtedly of political value to the President. For example, one related the activities of a former Roosevelt aide who was trying to influence the Truman administration's appointments. Another advised that the FBI had learned from a confidential source that a "scandal" was brewing and that it would be very embarrassing to the Democratic administration." A third contained the report of a "very confidential source" on a meeting of newspaper representatives in Chicago to plan publication of a series of stories exposing organized crime and corrupt politicians, stories which were going to be critical of the Attorney General and the President. The Truman White House also received a copy of an FBI memorandum reporting the contents of an in-house communication from Newsweek magazine reporters to their editors about a story they had obtained from the State Department. An example from the Eisenhower administration shows how White House requests and FBI initiative were sometimes mixed together.

President Eisenhower asked Director Hoover to brief the Cabinet on racial tensions in early 1956. What the Cabinet. received was a report not only on incidents of violence, but also on the activities of Southern Governors and Congressmen who were members of groups opposed to integration, the NAACP's plans to push for civil rights legislation, and the role of Communists in civil rights lobbying efforts. No one appears to have questioned the propriety of the FBI reporting such political intelligence, or Director Hoover's competence to do so.

The third source of abuse throughout the Bureau's history was its concern for its image and hostility to its critics. An example from the Truman years shows how the Bureau checked and reported on its critics. In 1949, the National Lawyers Guild planned to issue a report denouncing FBI surveillance activities which had been revealed in a court case. The FBI provided the Attorney General with advance information from its sources about the Lawyers Guild plans, as well as a full report on everything concerning that group in Bureau files. Attorney General Howard McGrath passed the reports on to the President, and J. Edgar Hoover advised the White House directly of last minute changes in the Guild's plans. The FBI's inside information allowed the Attorney General to prepare a rebuttal well in advance of the expected criticism.

A second example of the Bureau's reporting occurred during the Eisenhower administration, in 1960. The Tennessee Advisory Committee to the U.S. Civil Rights Commission had announced it would investigate charges by the Knoxville Area Human Relations Council that Federal agencies, including the FBI, were practicing racial discrimination. The Bureau conducted name checks on all 11 members of the Council's board of directors and forwarded the results to Attorney General William Rogers, Deputy Attorney General Lawrence Walsh, and Special Assistant to the Attorney General Harold R. Tyler, Jr. Derogatory information developed on four of these individuals included allegations of subversive connections from as 
far back as the late 1930's and early 1940's, an allegation that one board member had "corrupt political associates" in 1946, and the characterization of another as having "unorthodox attitudes" and sending flowers and "mash" notes to a woman in his church. The FBI's report also made, the flat statement, "Asyou know, this Bureau does not practice racial segregation or discrimination.” The committee will recall that it has previously received information as to the number of black FBI agents in the early 1960's. Thus, the Bureau's early history shows the development of its political services for higher authorities and its concern for its own political position.

The staff's investigation of alleged abuses in the 1960s and 1970s discloses a wide variety of questionable name checks, sometimes for Presidents and sometimes in the Bureau's own interest. An examination of these name check reports shows the peculiarly damaging nature of this practice. No new investigation was done to verify allegations stored away for years in FBI files. Anything anyone ever told the FBI about the individual was pulled together, including charges that the Bureau may have never substantiated. FBI files inevitably include misinformation because people bear grudges or make mistakes. Sometimes the Bureau verifies the charge; but frequently there is no reason to do so, and it is just recorded in the, files. Such charges can be retrieved by a name check and reported without, further substantiation.

A request by the Nixon White House for a name check on CBS news correspondent Daniel Schorr, which the FBI turned into a full field investigation, has been extensively examined elsewhere. The staff has determined that President Johnson asked for similar name check reports on at least seven other journalists, including NBC commentator David Brinkley ; Associated Press reporter Peter Arnett, who at about that time won a Pulitzer Prize for his reporting on Vietnam; and columnist Joseph Kraft. Another political abuse of FBI name checks occurred in the closing days of the 1964 Presidential election campaign, when Johnson aide Bill Moyers asked the Bureau to report on all persons employed in Senator Goldwater's office. Meyers has publicly recounted his role in the incident, and his account is confirmed by FBI documents. The committee may be interested in questioning Mr. DeLoach later today about this incident.

Some of President Johnson's requests parallel those of President Roosevelt 25 years earlier. In 1965, for example, the FBI complied with White House requests for name checks on dozens of persons who signed telegrams critical of U.S. Vietnam policy. The names of other Presidential critics were also sent to the Bureau to be checked and reported on, as were names of critics of the Warren Commission. The FBI has also volunteered reports on Presidential critics. Once again, Mr. DeLoach might be questioned on the practice of volunteering such information to the White House. The White House requests for name checks are episodic in comparison to name checks conducted as a matter of systematic Bureau policy for the use of FBI Director Hoover. The Crime Records Division, which was headed for a long period of time by Mr. DeLoach, prepared name check memorandums for Director Hoover regularly on congressmen, other public officials, and prominent persons of interest to the Director. Many of these special memorandums were filed by the Crime Records Division. Others found their way into Director Hoover's "Official and Confidential" files. The committee staff has located in these " 0 and C" files such special memorandums on the author of a book critical of the FBI, and on all members of the Senate subcommittee, chaired by Senator Long, which threatened to investigate the FBI in the mid-1960's. Some of these name check reports and special memorandums contained derogatory information and, in the case of the author, information about his income tax returns and personal information about his wife. The reports on members of the Long subcommittee were compiled in a briefing book, with tabs on each Senator.

These incidents demonstrate the inherent potential for abuse in the Bureau's unregulated name check procedure. White House requests bypassed the Attorney General, and the FBI Director's own requests took place totally within the Bureau. The real meaning of the longstanding fear that the FBI had so-called dossiers on Congressmen and other prominent persons, was the FBI officials could have name check reports prepared for their use on anyone about whom they desired to know more. 
The next category of abuse involves the Bureau's investigative powers. A vivid example of this type of abuse occurred during the Kennedy administration, when the FBI conducted late night and early morning interviews of a steel company executive, and several reporters who had written stories about that steel executive. Former Assistant FBI Director Courtney Evans, who will testify later this morning, may be questioned about this case.

Another example arises out of the Bobby Baker case. In 1965, the FBI declined a request of the Criminal Division, Justice Department to wire a witness in the investigation of former Johnson Senate aide Bobby Baker. Although the FBI refused on grounds that there was not adequate security, the Criminal Division had the Bureau of Narcotics in the Treasury Department wire the witness as a legitimate alternative. These events were revealed in 1967 when the Baker trial began. Presidential aide Marvin Watson informed the FBI that President Johnson was quite "exercised" and, in 1965, the Bureau was ordered to conduct a discrete rundown on the head of the Criminal Division and four persons in Treasury and the Narcotics BUIWU. These rundowns were specifically to include any associations with former Attorney General Robert Kennedy. Once again, Mr. DeLoach may be questioned on these matters.

Another incident occurred in 1966 when Mr. Watson requested that the FBI monitor the televised hearings of the Senate Foreign Relations Committee on Vietnam and prepare a memorandum comparing the statements of Senators Fulbright and Morse with "the Communist Party line." Once again, the documents in the committee's possession indicate Mr. DeLoach was involved in these activities. At the direct request of President Johnson to FBI executive Cartha DeLoach, the Bureau passed purely political intelligence about U.S. Senators to the White House which was obtained as a byproduct of otherwise legitimate national security electronic surveillance of foreign intelligence targets. This practice also continued under the Nixon administration at the request of Mr. H. R. Haldeman. This matter cannot be explored further in public session and must be reviewed in executive session because the details remain classified.

It is more difficult to automatically place the label "abuse” on Presidential requests for electronic surveillance to investigate leaks of classified information. In 1962, Attorney General Robert Kennedy authorized wiretaps on New York Times reporter Hanson Baldwin and his secretary. These wiretaps lasted for about 1 month. I would ask the Senators to turn to exhibit 36. In addition to the 1962 wiretap on Hanson Baldwin, the committee has just received materials from the FBI reflecting authorization by Attorney General Robert Kennedy of a wiretap on a reporter for Newsweek magazine in 1961 as part of the investigation of another leak of classified information. Further materials provided only last night by the FBI and the Justice Department reflect authorization by Attorney General Nicholas Katzenbach of a wiretap on the editor of an anti-Communist newsletter in 1965, again during the investigation of a leak of classified information.

The committee has received materials from the FBI reflecting authorization by Attorney General Robert F. Kennedy of wiretaps on at least six American citizens, including three executive branch officials, a congressional staff member, and two registered lobbying agents for foreign interests. The materials also reflect that these wiretaps related to an investigation of efforts by foreign interests to influence U.S. economic policies. The FBI has asked me to stress that the wiretap on the congressional staff member was not placed on a Capitol Hill office, but was rather placed on the residence, so that the FBI was not wiretapping on Capitol Hill.

The wiretaps under the Nixon administration of journalists and current or former White House and other executive officials have been widely publicized. The staff's inquiry into this matter has determined that, according to available records, at least one of these wiretaps had nothing to do with leaks and was conducted solely for personal information about the target. Nevertheless, the wiretapping Attorney General Kennedy authorized to investigate leaks and the taps of President Roosevelt's aides were 
undoubtedly precedents J. Edgar Hoover had in mind when he told President Nixon and Dr. Kissinger in 1969 that wiretaps had been used for these purposes in the past.

Another abuse of FBI investigative powers under the Johnson administration was the surveillance conducted at the 1964 Democratic National Convention in Atlantic City. This will be explored later with Mr. DeLoach. The most sensitive details of the plans and tactics of persons supporting the Mississippi Freedom Democratic Party delegate challenge were reported to the White House from the FBI's wiretap on Dr. King, and other types of FBI surveillance. The responsible White House official at the time, Mr. Walter Jenkins, has told the committee that he can recall no political use made of these reports. Nevertheless, an unsigned document has been located at the Johnson Library recording at least one political use of Mr. DeLoach's phone reports. As Theodore H. White's account of the 1964 campaign makes clear, the most important single issue that might have disturbed President Johnson at the Atlantic City Convention was the Mississippi challenge. And the FBI's own inquiry into the Atlantic City events reports several FBI agents' recollection that one purpose of the Bureau operation was to help avoid "embarrassment to the President." The committee must weigh all the evidence in deciding whether this abuse of the FBI resulted from a White House request, from FBI officials volunteering information to serve and please the President, or from a legitimate civil disorders intelligence operation which got out of hand because no one was willing to shut off the political intelligence byproduct. It should also be noted that an aide to Vice President Hubert Humphrey contacted the FBI to request assistance at the 1968 Chicago convention. Nothing appears to have come of this, largely because Attorney General Ramsey Clark turned down FBI requests for authorization to wiretap protest demonstration leaders at the Chicago convention. An additional instruction recorded in Bureau files from J. Edgar Hoover to the field office in Chicago prior to the Democratic convention directed that none of its activities should involve political intelligence.

1 would like now to turn to the first addendum of the staff report, exhibit 36 . According to materials provided to the committee by the FBI, President Johnson asked the Bureau to conduct physical surveillance of Mrs. Anna Chennault, a prominent woman Republican leader, on October 30, 1968, in the final days of the election campaign. The FBI instituted this surveillance to cover her activities in Washington, D.C and New York City. The results of this physical surveillance were disseminated to J. Bromley Smith, Executive Secretary of the National Security Council, who had conveyed Johnson's request to Cartha DeLoach of the FBI. On November 7,1968, Smith called DeLoach and stated that President Johnson wanted the FBI to abandon its physical surveillance of Mrs. Chennault. On November 13,1968, at the instruction of President Johnson, the FBI checked the toll call telephone records in Albuquerque, N. Mex., to determine if Vice Presidential Candidate Spiro Agnew had called Mrs. Chennault or the South Vietnamese Embassy during his November 2, 1968, visit to Albuquerque. No such records were located. President Johnson was furnished this information on November 13, 1968. Agnew's arrival and departure time to Albuquerque on November 2, 1968 were also verified at the request of the White House. The FBI has reviewed its files on this matter and has advised that the apparent reason the White House was interested in the activities of Mrs. Chennault and Spiro Agnew was to determine whether the South Vietnamese had secretly been in touch with supporters of Presidential Candidate Nixon, possibly through Mrs. Chennault. President Johnson apparently was suspicious that the South Vietnamese were trying to sabotage his peace negotiations in the hope that Nixon would win the election and then take a harder line toward North Vietnam. The FBI also states that physical surveillance of Mrs. Chennault was consistent with FBI responsibilities to determine if her activities were in violation of certain provisions of the Foreign Agents Registration Act and of the Neutrality Act.

The committee has also inspected copies of reports to the White House of the physical surveillance of Mrs. Anna Chennault. These include her leaving the Watergate apartments, leaving her residence, proceeding to New York, visiting the Embassy of Vietnam, traveling again to the Embassy of Vietnam, and being transported by cab from the vicinity of the Vietnamese Embassy to the Investment Building on 
I Street in Northwest Washington, DC. Further details of these events involving electronic surveillance remain classified "Top Secret." Finally, there are two additional examples of political abuse of or by the FBI in the seventies, In July 1971, 3 months after the supposed end of FBI COINTELPRO operations, the FBI leaked to a newsman derogatory public record information about Daniel Ellsberg's lawyer [exhibit 371]. Copies of the article were sent to the Attorney General, the Deputy Attorney General, and Presidential Aide H. R. Haldeman with the specific approval of Director Hoover, with no indication it was generated by the FBI. Nevertheless, the committee should note that Charles Colson, who pleaded guilty to a civil rights offense for leaking information about Daniel Ellsberg's lawyer to a journalist, had told that he believed that the FBI was doing the same thing. In May of 1070, the FBI provided derogatory public record information and other allegations about the Reverend Ralph David Abernathy, president of the Southern Christian Leadership Conference, to Vice President Agnew at his request [exhibit 38]. This occurred following a telephone conversation between FBI Director Hoover and Mr. Agnew during which, according to Bureau records, the Vice President "said he thought he was going to have to start destroying Abernathy's credibility.”

In summary, political abuse of the FBI and by the FBI has extended over the years through administrations of both parties.

Senator TOWER. Thank you, Mr. Elliff. 


\section{Appendix 4}

\section{Terrorist Screening Center Director Donna A. Bucella's Statement to the National Commission on Terrorist Attacks Upon the United States, January 26, 2004}

The TSC has approached the challenge to consolidate terrorists watch lists by implementing a “phased in” approach. Since December 1, 2003, the TSC has had the ability to: (1) make the names and identifying information of terrorists, known to or suspected by the U.S. Government, accessible to federal, state and local law enforcement; (2) have a system for properly reviewing whether a known or suspected terrorist should be included in or deleted from additional screening processes; (3) administer a process to ensure that persons, who may share a name with a known or suspected terrorist, are not unduly inconvenienced in U.S. Government screening processes; and, (4) implement a system to adjust or delete outdated or incorrect information to prevent problems arising from misidentifications.

By this summer, TSC will have a single, consolidated Terrorist Screening Database (TSDB). Before the end of this year, the TSC will create a more dynamic database and use a single, integrated system for ensuring known or suspected terrorists' identities are promptly incorporated into all appropriate screening processes. The terrorist screening database will allow private sector entities, such as operators of critical infrastructure facilities or organizers of large events, to submit a list of persons to the U.S. Government to identify possible terrorists. In addition, the TSC will begin to implement mechanisms for sharing terrorist screening information with cooperating countries. 


\section{Appendix 5}

\section{Terms for the directed graph, Figure 5:}

Director - the head of the FBI

Operational Divisions - Criminal Investigative, Counterintelligence, Counterterrorism, Cyber

Support Divisions - Inspection, Human Resources, Information Technology

State, Local, Tribal Police - All non-federal law enforcement

Congress - Senate, House of Representatives, staff

Commissions - 9/11, WMD

Information Technology Systems - Automated systems used by the Intelligence Community

Analyst - FBI Intelligence Analyst or Supervisory Intelligence Analyst

Agent - FBI Special Agent or Supervisory Special Agent

Training - All education geared toward transformation into an intelligence-based FBI

Translation - The capability to translate documents and voice intercepts

Recruiting - Actions taken to recruit and hire FBI Intelligence Analysts

Retention - Actions taken to retain FBI Intelligence Analysts following graduation from entry level

training

Fusion Centers - The collective group of 70+ designated and operational state and urban fusion centers

Laws/Regulations - Laws, regulations, and Attorney General Guidelines relating to domestic intelligence

collection

Intelligence Community - The collective group of 17 designated agencies ${ }^{98}$

Terrorism - The FBI Counterterrorism Program targets

${ }^{98}$ The full list of these agencies can be accessed at: http://www.intelligence.gov/about-the-intelligence-community/ 
Espionage - The FBI Counterintelligence Program targets

Crime - All criminal activity the FBI investigates

Intelligence Cycle - The five step, circular process of planning, collection, processing, analysis, and dissemination

Field Offices - The FBI’s 56 field offices

International Partners - The country agencies with which the FBI shares intelligence

Legal Attachés - The FBI's 60 offices outside the U.S.

Resources - Budget and manpower

Presidential Daily Brief - The daily brief provided from the IC to the President and NSC

White House - The President and NSC

Change Management - The process of evolving group culture

Culture - The FBI's law enforcement, reactive culture

Bureaucracy - Stakeholders in the anti-change process

Testimony - Provided by agents and lab technicians at trial

Evidence - Items collected during an investigation for use at trial

Sources - Persons who provide information or intelligence

Directorate of Intelligence - The FBI's entity for implementing the Intelligence Cycle

Executives - FBI personnel at the GS-15 and SES level

War - Locations where U.S. troops are engaged with hostile forces

Prosecution - Actions taken by a prosecutor to convict

Reports - Intelligence products created by FBI intelligence analysts 


\section{Bibliography}

Andre, Louis E. "Intelligence Production: Towards a Knowledge-Based Future." Defense Intelligence Journal (Fall 1997): 34-45.

Andreas, Peter and Price, Richard, "From War Fighting to Crime Fighting: Transforming the American National Security State,” International Studies Review, Vol. 3, No. 3 (Autumn, 2001), pp. 31-52.

Banach, Stefan J., et al. Art of Design Student Text, Version 2.0, Fort Leavenworth: School of Advanced Military Studies: 2010.

Barger, Deborah G. "It Is Time to Transform, Not Reform, U.S. Intelligence." SAIS Review 24, No.1, 2331.

Batvinis, Raymond J. The Origins of FBI Counterintelligence. Lawrence: University Press of Kansas: 2007.

Cumming, Alfred and Masse, Todd. FBI Intelligence Reform Since September 11, 2001: Issues and Options for Congress, Washington, DC: Library of Congress: 2004.

Cumming, Alfred and Masse, Todd. Intelligence Reform Implementation at the Federal Bureau of Investigation: Issues and Options for Congress, Washington, DC: Library of Congress: 2005.

Department of Defense, Joint Publication 1-02 Department of Defense Dictionary of Military and Associated Terms, Washington, DC: 2011.

Department of Justice. A Review of the FBI's Handling of Intelligence Information Related to the September 11 Attacks. Washington, DC: 2004.

Department of Justice. Report to the National Commission on Terrorist Attacks Upon the United States: The FBI's Counter terrorism Program Since September 2001, Washington, DC: U.S. Department of Justice, 2004.

Headquarters, Department of the Army, FM 5-0, The Operations Process, Washington, DC: 2010.

Elliff, John T. The Reform of FBI Intelligence Operations. Princeton, NJ: Princeton University Press: 1979.

Falkenrath, Richard A. "Problems of Preparedness: U.S. Readiness for a Domestic Terrorist Attack," International Security 25, No. 4 (Spring, 2001), 147-186.

Gertz, Bill. Breakdown: How America's Intelligence Failures Led to September 11. Washington, DC: Regnery: 2002.

Gharajedaghi, Jamshid. Systems Thinking, Amsterdam: Elsevier: 2006.

Hansen, James. "U.S. Intelligence Confronts the Future." International Journal of Intelligence and CounterIntelligence (Winter 2004/2005): 673-709.

Hitz, Frederick P. and Brian J. Weiss. "Helping the CIA and FBI Connect the Dots in the War on Terror," International Journal of Intelligence and CounterIntelligence (Spring 2004): 1-41.

Jeffreys-Jones, Rhodri. The FBI : a History. New Haven: Yale University Press, 2007.

McCarthy, Andrew C. "The Intelligence Mess; How It Happened, What to Do About It," Commentary (April 2004): 11-20. 
Lawson, Bryan. How Designers Think: The design process demystified. Oxford: Elsevier, 2006.

Libicki, Martin C. and Pfleeger, Shari Lawrence, Collecting the Dots Problem Formulation and Solution Elements, Rand Corporation Report OP-103-RC: 2004

Miller, John. The Cell: Inside the 9/11 plot and Why the FBI and CIA Failed to Stop It. New York: Hyperion: 2002.

National Commission On Terrorist Attacks Upon the United States. 9/11 Commission Report. New York: W.W. Norton: 2004.

O’Reilly, Kenneth. “A New Deal for the FBI: The Roosevelt Administration, Crime Control, and National Security,” The Journal of American History 69, No. 3 (Dec., 1982), 638-658 .

Perrow, Charles, “Organizational or Executive Failures?” Contemporary Sociology, Vol. 34, No. 2 (Mar., 2005), pp. 99-107.

Posen, Barry R. “The Struggle against Terrorism: Grand Strategy, Strategy, and Tactics,” International Security, Vol. 26, No. 3 (Winter, 2001-2002), pp. 39-55

Ransom, Harry Howe. "Being Intelligent about Secret Intelligence Agencies,” The American Political Science Review 74, No. 1 (Mar., 1980), 141-148

Riebling, Mark. Wedge: the Secret War Between the FBI and CIA. New York: A.A. Knopf: 1994.

Rivkin, Jan W., Roberto, Michael. Federal Bureau of Investigation, 2001, Cambridge: Harvard Business School: 2001.

Rivkin, Jan W., Roberto, Michael, Gulati, Ranjay. Federal Bureau of Investigation, 2007, Cambridge: Harvard Business School: 2007.

Rivkin, Jan W., Roberto, Michael, Gulati, Ranjay. Federal Bureau of Investigation, 2009, Cambridge: Harvard Business School: 2009.

Rivkin, Jan W., Roberto, Michael, Gulati, Ranjay. Managing National Intelligence (A): Before 9/11, Cambridge: Harvard Business School: 2006.

Russell, Richard L. "Intelligence Failures: The Wrong Model for the War on Terror." Policy Review (February/March 2004): 61-72.

Theoharis, Athan G. The FBI: An Annotated Bibliography and Research Guide. New York: Garland: 1994.

Theoharis, Athan G. “FBI Wiretapping: A Case Study of Bureaucratic Autonomy,” Political Science Quarterly, Vol. 107, No. 1 (Spring, 1992), pp. 101-122

U.S. Senate Committee on Homeland Security and Governmental Affairs, A Ticking Time Bomb, Counterterrorism Lessons from the U.S. Government's Failure to Prevent the Fort Hood Attack, Washington, DC: 2011.

U.S. Senate Select Committee to Study Governmental Operations with Respect to Intelligence Activities, Volume 6, Exhibit 19-2, Washington, DC: Government Printing Office: 1976.

Zegart, Amy B. Spying Blind: the CIA, the FBI, and the Origins of 9/11. Princeton, N.J.: Princeton University Press: 2007. 